\title{
9. Creative Commons and Related Rights in Sound Recordings: Are the Two Systems Compatible?
}

by Christina Angelopoulos, Institute for Information Law, University of Amsterdam

\subsection{Introduction'}

Modern technologies have made the dissemination of creative works over the internet child's play, while technological advancements have changed the face of even traditional methods of circulation. A multitude of innovative media, formats and infrastructure provide users with new ways of accessing cultural products, something which is especially evident in the field of musical works. Today, music surrounds us and accompanies us into bars and restaurants as we unwind with friends, on the car radio as we head off to work or emanating from our computer's loudspeakers, either unexpectedly when we click into a website or according to our express intention when we tune into internet radio services. We even have the technical possibility of downloading and streaming specific tracks at a time and place of our liking, through recipient-initiated media or creating our own musical works and sharing them with others online. Yet even these modern technologies are not outside the reach of copyright law; the constraints copyright imposes apply even to the works of authors who wish to take advantage of modern technologies in order to achieve a broad and free dissemination of their work.

In response to the consequent demand for more freedom in the sharing of creative content, open content licenses began to emerge at the beginning of the twenty-first century. The term refers to so-called 'some rights reserved' licenses, which enable the owners of rights in creative content to grant certain freedoms over their works, allowing others to access, distribute or even modify them. Today the most well-known set of open access licenses is the one developed by Creative Commons (CC). For a variety of different reasons, the attachment of Creative Commons licenses to creative works may not always go smoothly, however. In

I. With many thanks to Lucie Guibault and Stef van Gompel for many helpful discussions and comments. 
the specific case of musical works, a particularly thick parcel of varying intellectual property rights adds complexity to their release under the terms of a Creative Commons license: besides the author's exclusive economic and moral rights that may subsist in the music or lyrics themselves, the performance of the music or lyrics and the phonogram onto which this performance has been fixated will also be the subject of so-called neighbouring or related rights. In order to fully release a phonogram from the rights subsisting in it according to copyright and related rights legislation, performers and phonogram producers must also agree, along with the author, to license their neighbouring rights by means of a Creative Commons license. But if they choose to do so, are they afforded this option under the law?

Under the European copyright directives, related rights owners are granted a broad range of exclusive economic rights, covering, broadly speaking, the fixation, communication to the public and broadcasting by wireless means of performances and the reproduction, distribution, rental, lending and making available to the public of the phonograms onto which these performances have been fixated. For the most part, the licensing of uses protected by exclusive related rights through the application of Creative Commons licenses raises the same issues as those presented in the case of author's rights. ${ }^{2}$ In addition to these exclusive rights, however, performers and phonogram producers are also granted a right to equitable remuneration for the use of their phonograms in communications to the public or broadcasting by wireless means. The right to equitable remuneration is of particular interest in relation to the application of CC licenses to phonograms, as it has been incorporated into the national law of many EU Member States in the form of a (waivable or non-waivable) compulsory license scheme for purposes of more effective enforcement and management. Even where a voluntary license scheme is in place, however, the flexibility that this will allow rights owners in relation to the combination of different methods of exploiting their rights over their performances and phonograms will be questionable or limited. Given this context, the following question must be addressed: is the legal framework of related rights and the collective management systems in place for the exploitation of these rights compatible with the use of Creative Commons licenses? It is important to note that the Creative Commons licensing suite accommodates these diverging eventualities by adopting licensing terms that enable the attachment of a license, even where such schemes are in place. In the case of non-waivable compulsory license schemes, CC licenses establish that the licensor reserves the right to collect royalties for the exercise of the rights granted under

2. For a comprehensive analysis of what such issues might involve, see Dusollier, S. (20007), 'Sharing Access to Intellectual Property through Private Ordering' Chicago-Kent Law Review 82 (3):I39I. 
the license. If a waivable compulsory license scheme or a voluntary license scheme are in place, the CC licenses state that the licensor waives this right. ${ }^{3}$

In order to answer this question, Part 2 of this chapter will take a detailed look at the provisions on the right to equitable remuneration of performers and phonogram producers as established in the Rome Convention, the WIPO Performances and Phonograms Treaty, the Rental Right Directive and the InfoSoc Directive, as well as the national legislation of two EU Member States. For this purpose the examples of the Netherlands and the UK have been selected, as representative of, respectively, the civil and common law traditions in Europe, but also due to the interesting particularities exemplified in their jurisdictions in relation to the right of equitable remuneration. This analysis shall be done in order to precisely determine the field of application of the right. In order to avoid conflating the field of application of the right to equitable remuneration with that of the making available right, which also involves the dissemination of a work to the public, the international, European and national (Dutch and UK) provisions related to this right will also be examined. A clear division between acts that fall within the ambit of the exclusive making available right on the one hand, and the communication to the public and broadcasting that activate the right to equitable remuneration on the other, is particularly important given the fact that no distinction is made in the CC licenses themselves between these different types of use. As a result, it is not possible to attach a license to a phonogram that only allows the user to make it available to the public, but not to broadcast it or communicate it to the public. This, in turn, means that no CC license that does not implicate the right to equitable remuneration currently exists. In Part 3, an examination of the particulars of the collective management regimes set up for the right to equitable remuneration in the Netherlands and the UK shall be undertaken. Here, an attempt shall also be made to allocate the license schemes for the collection and distribution of equitable remuneration in these two Member States to the categories of license schemes identified in the CC licenses (non-waivable compulsory license scheme, waivable compulsory license scheme and voluntary compulsory license scheme). Finally, in Part 4, conclusions will be drawn regarding the compatibility of the two systems and the ways in which related rights should be handled, in order to enable maximum advantage for both rights holders and users from the application of Creative Commons licenses. In order to illustrate these results, they shall be applied to the examples of two music-related internet

3. It should be noted that the terms in the CC licenses related to license schemes differ slightly depending on the type of license: According to CC licenses with a non-commercial clause, i.e. licenses that enable licensees to use the licensed work (and possibly derivative works based upon it) for non-commercial purposes only, in the case of waivable compulsory license schemes and voluntary license schemes, the licensor waives the right to collect royalties only for uses on the part of the licensee that are non-commercial, as defined in the license. 
platforms, Last.fm and Simuze.nl. The first is an internet radio and music community website, while the second is an online open content community where music is uploaded by the authors/performers themselves under the terms of a Creative Commons license of their selection.

\subsection{Defining the Subject Matter of Related Rights in Sound Recordings}

In November 1992, the Council of Ministers of the European Community adopted Directive 92/I00/EC 'on rental right and lending right and on certain rights related to copyright in the field of intellectual property', otherwise known as the Rental Right Directive. It was the second Directive to be adopted on the European level in the field of copyright and related rights, but the first to attempt a broad and comprehensive harmonization of rights in this area. ${ }^{4}$ Among other things, the Rental Right Directive introduces in the European acquis communautaire certain neighbouring rights appertaining to different categories of rights holders, including the rights of broadcasting and communication to the public of performers and phonogram producers. According to Article 8(2) of the EU's Rental Right Directive: ${ }^{5}$

Member States shall provide a right in order to ensure that a single equitable remuneration is paid by the user, if a phonogram published for commercial purposes, or a reproduction of such phonogram, is used for broadcasting by wireless means or for any communication to the public, and to ensure that this remuneration is shared between the relevant performers and phonogram producers.

The article introduces an economic remuneration right to the benefit of performing artists and producers of sound recordings for the use of such sound recordings for broadcasting or communication to the public. The right is distinctive in that it institutes a statutory license in exchange for equitable remuneration, thereby establishing that, contrary to what would be the case with an exclusive right, any broadcasting or communication to the public of the work is permissible, even

4. Hugenholtz, P. B. (2005), 'Copyright without Frontiers: is there a Future for the Satellite and Cable Directive?', in Die Zukunft der Fernsehrichtlinie/The Future of the 'Television without Frontiers' Directive, Proceedings of the conference organized by the Institute of European Media Law (EMR) in cooperation with the European Academy of Law Trier (ERA), Schriftenreihe des Instituts für Europäisches Medienrecht (EMR), Band 29, Baden-Baden: Nomos Verlag. Available at: www. ivir.nl/publications/hugenholtz/copyrightwithoutfrontiers.html.

5. Directive 2006/II5/EC of the European Parliament and of the Council of I2 December 2006 on rental right and lending right and on certain rights related to copyright in the field of intellectual property [2006] OJ L376/28 (hereafter: Rental Right Directive). 
without the rights holder's explicit authorization, as long as equitable remuneration is paid by the user. In practice, equitable remuneration is usually collected by collective management organizations on behalf of performers and phonogram producers.

In addition to the right to equitable remuneration, performers are granted a series of exclusive rights under the European Directives. To begin with, Article 8 (I) Rental Right Directive states that:

Member States shall provide for performers the exclusive right to authorise or prohibit the broadcasting by wireless means and the communication to the public of their performances, except where the performance is itself already a broadcast performance or is made from a fixation.

The article grants performers an exclusive right, i.e. a right to authorize or prohibit, in relation to the broadcasting by wireless means and communication to the public of unfixed performances (live performances). The broadcasting by wireless means and communication to the public of performances that have already been broadcast or are fixations of performances are explicitly excluded from the scope of the right, as are, by consequence, the repeated broadcasting or rebroadcasting of the first broadcast made from a personal performance. ${ }^{6}$ Phonogram producers are not protected under the provision, a logical consequence of the exclusion of fixed performances from the reach of the right.

In May 200I, Directive 200I/29/EC 'on the harmonisation of certain aspects of copyright and related rights in the information society' was adopted by the European Parliament and the Council. In Article 3(2), the InfoSoc Directive ${ }^{7}$ provides that:

Member States shall provide for the exclusive right to authorise or prohibit the making available to the public, by wire or wireless means, in such a way that members of the public may access them from a place and at a time individually chosen by them: (a) for performers, of fixations of their performances; (b) for phonogram producers, of their phonograms.

Article 3(2) InfoSoc Directive grants performers and phonogram producers an exclusive right to the making available to the public, by wire or wireless means, of fixations of their performances and their phonograms respectively, in such a

6. Reinbothe, J. \& S. van Lewinski (1993), The EC Directive on Rental and Lending Rights and on Piracy, London: Sweet \& Maxwell, p. 95.

7. Directive 200I/29/EC of the European Parliament and of the Council of 22 May 200I on the harmonization of certain aspects of copyright and related rights in the information society [200I] OJ LI67/Io (hereafter: InfoSoc Directive). 
way that members of the public may access them from a place and at a time individually chosen by them. Correctly determining when rights holders are protected with the exclusive making available right and when with the right to equitable remuneration will form a significant part of the analysis below.

The European provisions on copyright and related rights lean heavily on the corresponding provisions of the international WIPO Treaties. Article 3(2) InfoSoc Directive implements ${ }^{8}$ Articles Io and I4 of the WIPO Performances and Phonograms Treaty (WPPT), ${ }^{9}$ which was signed in December 1996 . These provide the following:

Article 10: 'Performers shall enjoy the exclusive right of authorizing the making available to the public of their performances fixed in phonograms, by wire or wireless means, in such a way that members of the public may access them from a place and at a time individually chosen by them'.

Article 14: 'Producers of phonograms shall enjoy the exclusive right of authorizing the making available to the public of their phonograms, by wire or wireless means, in such a way that members of the public may access them from a place and at a time individually chosen by them'.

In fact, this 'new' making available right debuted in the 1996 WIPO Internet Treaties, as an integral part of their 'digital agenda', a bid on the part of the Contracting Parties to modernize the international copyright and related rights framework and address the unconventional avenues for exploitation opened by means of innovative technologies.

The WPPT also includes a provision on the right of performers and phonogram producers to equitable remuneration. According to Article I5(I) WPPT:

Performers and producers of phonograms shall enjoy the right to a single equitable remuneration for the direct or indirect use of phonograms published for commercial purposes for broadcasting or for any communication to the public.

The history of the right to equitable remuneration however originally goes back to the 196r Rome Convention. ${ }^{\text {Io }}$ In Article 12, this Treaty states the following:

8. InfoSoc Directive, Recital I5.

9. WIPO Performances and Phonograms Treaty (adopted 20 December 1996, entered into force 20 May 2002) S. Treaty Doc. No. I05-I7 (I997) (hereafter: WPPT), Article I5.

Io. International Convention for the Protection of Performers, Producers of Phonograms and Broadcasting Organizations (adopted 26 October I96I, entered into force I8 May I964) 496 U.N. T.S. 43 (hereafter: Rome Convention), Article I2. 
If a phonogram published for commercial purposes, or a reproduction of such phonogram, is used directly for broadcasting or for any communication to the public, a single equitable remuneration shall be paid by the user to the performers, or to the producers of the phonograms, or to both. Domestic law may, in the absence of agreement between these parties, lay down the conditions as to the sharing of this remuneration.

The WIPO Treaties create international obligations among Contracting States ${ }^{\text {II }}$ and are, therefore, intended to regulate international situations involving copyright and related rights. Such situations may also arise between EU Member States who have signed and ratified the Treaties; whether the Treaties and their definitions will be directly applicable in such cases will depend on national constitutional provisions dictating how international treaties are to be transposed into domestic law, as well as the extent to which the provisions of the Treaties themselves can be seen as self-executing. ${ }^{\mathrm{I}}{ }^{2}$ In any case, the WIPO Treaties will not be directly applicable to domestic disputes within the jurisdictions of the individual signatory states.

At the same time, however, it is important to note that the Rome Convention was adopted before the EU's Rental Right Directive and its provisions had a direct effect on the original text of the European legislator when that Directive was first adopted in 1992. The same is not true of the considerably younger WPPT, although the subsequent 200I InfoSoc Directive in Recital 6I requested the amendment of the Rental Right Directive with a view to bringing it into full compliance with that Treaty. Indeed, the Rental Right Directive was subsequently amended in accordance with the WPPT in 200I and eventually codified in 2006. In any case, as opposed to the WIPO Treaties, which provide elaborate sets of definitions for the relevant legal terms, the European acquis contains relatively few rules in the field of related rights. The European legislator seems, instead, to have relied on the harmonizing effect of the WIPO Treaties on the laws on the individual Member States. ${ }^{13}$

Accordingly, in the analysis below, the definitions of the subject matter of the right to equitable remuneration provided by this international quasi-acquis ${ }^{\mathrm{I}}$ shall be examined in parallel to those that can be found in the EU Directives them-

II. See Rome Convention, Article 4 and 5 and WPPT Article 3.

I2. Walter, M. (2000), 'The Relationship of, and Comparison between, the Rome Convention, the WIPO Performances and Phonograms Treaty (WPPT) and the Agreement on Trade-Related Aspects of Intellectual Property Rights (TRIPS Agreement); the Evolution and Possible Improvement of the Protection of the Neighbouring Rights Recognized by the Rome Convention', Copyright Bulletin 4 (34):3.

13. Van Eechoud, M. et al. (2009), Harmonizing European Copyright Law: The Challenges of Better Lawmaking, The Hague: Kluwer Law International, p. 7I et seq.

I4. Ibid., p. 73. 
selves, although precedence will be given to the latter. In addition, the implementation of the provisions in the legislation of EU Member States shall also be examined, in order to detect any divergences from the international and European norm in domestic legislation. For this purpose, the relevant rules of the Dutch Wet op de Naburige Rechten (Neighbouring Rights Act - WNR) ${ }^{15}$ and the UK's Copyright, Designs and Patents Act (CDPA) ${ }^{\mathrm{I} 6}$ shall be examined, though the corresponding laws of other countries might also be inspected where they can offer additional insight. In this regard, it is important to keep in mind that Article 8(2) Rental Right Directive establishes only minimum protection and that, consequently, EU Member States are free to grant the owners of related rights more far-reaching protection, should they choose to do so. ${ }^{17}$ The definitions of the following terms shall be examined: 'phonogram' and a 'reproduction of a phonogram', 'publication for commercial purposes', 'broadcasting', 'making available to the public' and 'communication to the public'.

\subsubsection{Phonogram and Reproduction of a Phonogram}

According to the WPPT, a phonogram is 'the fixation of the sounds of a performance or of other sounds, or of a representation of sounds, other than in the form of a fixation incorporated in a cinematographic or other audiovisual work'. This definition is updated in relation to the more archaic one provided by the Rome Convention, which gives 'phonogram' as 'any exclusively aural fixation of sounds of a performance or of other sounds' ${ }^{18}$ The main difference concerns its extension to those phonograms that are not a fixation, but a representation of sounds, a modification necessary in view of digital technologies that enable the generation of sound through the fixation of data, even if the corresponding sounds have not existed before. ${ }^{19}$ It should be concluded that musical works found online in digital form do indeed qualify as phonograms within the meaning of the WPPT.

The WPPT excludes from the definition of a phonogram any 'fixation incorporated in a cinematographic or other audiovisual work'. As a result, the WIPOadministered Treaties do not provide a right to remuneration for the broadcasting

I5. Wet van I8 maart 1993, houdende regelen inzake de bescherming van uitvoerende kunstenaars, producenten van fonogrammen of van eerste vastleggingen van films en omroeporganisaties en wijziging van de Auteurswet I9I2 [I8 March I993] Official Gazette I78 (hereafter: Wet op de Naburige Rechten or WNR).

I6. Copyright, Designs and Patents Act (ST i988 c. 48) (hereafter: CDPA I988).

17. Rental Right Directive, Recital I6.

I8. Rome Convention, Article 3(b).

I9. Lucas, A. \& H.J. Lucas (200I), Traité de la propriété littéraire et artistique ( ${ }^{\text {nd }}$ ed.), Paris: Litec, p. 629; Fiscor, M. (2003), Guide to the Copyright and Related Rights Treaties Administered by WIPO and Glossary of Copyright and Related Rights Terms, Geneva: World Intellectual Property Organization (WIPO), p. 234 
and communication to the public of recordings with both a visual and a sound element. ${ }^{20}$ Attention must be paid to the precise wording, however, as it enables protection in cases where an audiovisual fixation does not qualify as a cinematographic or other audiovisual work for the fixation of the sounds of the performance. In addition, Agreed Statement 2 of the WPPT makes clear that the rights in phonograms are not affected by their incorporation into cinematographic or other audiovisual works. ${ }^{2 \mathrm{I}}$ So, if the soundtrack for a film is fixed separately and only later incorporated into the audiovisual work, equitable remuneration will be due to the performers and producers according to the WPPT for use of the phonogram in a broadcast or communication to the public. Equitable remuneration will also be due when the soundtrack is not released as a separate phonogram, if the film does not qualify for protection as an audiovisual work.

No definition of either the expression 'phonogram' or 'reproduction of a phonogram' is specifically provided by the EU copyright directives. Reinbothe and von Lewinski assure that all technical formats and methods of recording are covered, such as pre-recorded music cassettes, LPs and compact disks, and also state that, as with the WPPT, audiovisual recordings ('videograms') are not included (although, as opposed to the WPPT, no further clarification concerning the possibility of separate fixation of the sound fixation and later incorporation into an audiovisual work is explicitly made).

As Article 8(2) Rental Right Directive only offers minimum protection for rights holders, EU Member States are free to expand protection to include audiovisual fixations. This has been the case in Germany, where remuneration is collected for the broadcasting and communication to the public of music videos, as well as in Spain, Croatia and Belgium, where all audiovisual fixations are covered. $^{22}$

In the Netherlands, Article I(c) WNR defines a phonogram as 'any recording of the sounds only of a performance or of other sounds'. The phrase 'sounds only' could be taken to indicate that fixations of sound which are incorporated into a film at a later date to that of the original fixation are also covered, bringing the

20. It should be noted that this makes sense from an etymological point of view as well, as the term 'phonogram' is a compound noun, coined from the Greek ' $\varphi \omega v \eta$ ', meaning 'voice, sound', and ' $\gamma \rho \alpha \dot{\alpha} \mu \alpha \alpha$ ', meaning 'something written', and therefore refers solely to fixations of sound, rather than of visual elements.

2I. Fiscor, M. (2003), Guide to the Copyright and Related Rights Treaties Administered by WIPO and Glossary of Copyright and Related Rights Terms, Geneva: World Intellectual Property Organization (WIPO), p. 235.

22. See, German Gesetz über Urheberrecht und verwandte Schutzrechte (Copyright and Neighbouring Rights Act - UrhG), [9 September 1969] Official Gazette, Part I, p. I273, Article 78\$2 and E. Vanheusden, 'Performers' Rights in European Legislation: Situation and Elements for Improvement' (AEPO-ARTIS, June 2007). Available at: www.aepo-ARTIS.org/usr/AEPO-ARTIS\%20Studies/Study\%2oPerformers\%2oRights\%2oin\%20Acquis_AEPO-ARTIS.pdf. 
Dutch definition close to that of the WPPT. This interpretation is confirmed by the Dutch literature. Audiovisual recordings are not protected, although the Dutch collecting society SENA has unilaterally taken it upon itself to collect equitable remuneration for video-clips as well, along the reasoning that these constitute reproductions of phonograms. ${ }^{23}$

The UK, following the common law tradition, does not use the term 'phonogram' in its relevant provisions at all. Instead, the expression 'sound recording' is employed. Section $5 \mathrm{~A}$ of the CDPA defines a sound recording as '(a) a recording of sounds, from which the sounds may be reproduced, or (b) a recording of the whole of any part of a literary, dramatic or musical work, from which sounds reproducing the work or part may be produced, regardless of the medium on which the recording is made or the method by which the sounds are reproduced or produced'. ${ }^{24}$ The use of the term sound recording itself implies that audiovisual fixations are not protected by a right to equitable remuneration. ${ }^{25}$ Section $5 \mathrm{~B}$ CDPA states that ' $[\mathrm{t}]$ he sound track accompanying a film shall be treated as part of the film', but that copyright subsisting in a film does not affect 'any copyright subsisting in a film sound track as a sound recording', bringing the CDPA perfectly into line with the WPPT.

\subsubsection{Publication for Commercial Purposes}

According to Article 2(e) WPPT, "publication' of a fixed performance or a phonogram means the offering of copies of the fixed performance or the phonogram to the public, with the consent of the rights-holder, and provided that copies are offered to the public in reasonable quantity'. Furthermore, according to Agreed Statement (3) of the Treaty, the word 'copies' in this context exclusively covers fixed copies that can be put into circulation as tangible objects. The expression 'publication', therefore, within the meaning of the WPPT, would seem to cover solely the traditional method of distribution of physical copies of pre-recorded sound recordings in the form of LPs, magnetic tapes or CDs in a quantity suitable to satisfy the reasonable requirements of the public.

According to the provisions of the WPPT, such publication is required to be for 'commercial purposes'. A casual reading of the WPPT would, at first, encourage identifying commercial purposes with financial gain; as Ricketson and Ginsburg point out, Article 2(e) seems to imply that 'publication could take place through

23. Visser, D.J.D. (1999), Naburige Rechten : van Uitvoerende Kunstenaars, Fonogrammenproducenten, Filmproducenten en Omroeporganisaties, in Deventer: W.E.J. Tjeenk Willink, p. 72; Spoor, J., Verkade, D. \& D. Visser (2005), Austeursrecht, naburige rechten en databankenracht, Deventer: Kluwer, p. 66r.

24. CDPA, s. 5A. The definition is included in Part I of the Act on copyright, but its application is expanded to Part II on rights in performances as well, by means of the provision of s. 2II (I).

25. See also above, ft $2 \mathrm{I}$. 
the means of a gratuitous distribution or 'giveaway', whereas the qualifying phrase 'for commercial purposes' implies that some pecuniary benefit, whether or not in terms of money, should be intended'. ${ }^{26}$ Article 15(4) of the WPPT however introduces a derogation from the definition of publication applicable to the rest of the Treaty limited exclusively to the case of equitable remuneration: 'phonograms made available to the public by wire or wireless means in such a way that members of the public may access them from a place and at a time individually chosen by them shall be considered as if they had been published for commercial purposes'. ${ }^{27}$ Consequently, a broader definition of publication for commercial purposes must be adopted, which, apart from publication for commercial gain, also encompasses online on-demand services. In the specific case of publication as described in Article 15(4), the commercial nature of the purpose is not relevant. As Ficsor states, the phonogram 'is to be regarded as if it had been published [...] and as if the publication had been for commercial purposes, irrespective of whether or not there is any commercial purpose or impact at all behind the act'. ${ }^{28}$ Such a definition will also be obliged to defer to the distinction analysed below (see section 2.3) between the act of communication to the public (which will not necessarily constitute commercial publication) and that of making available to the public (which always will).

We must therefore conclude that, publication of a phonogram or a fixed performance will constitute publication for commercial purposes within the meaning of Article I5 WPPT, when either:

(a) a phonogram is made available by wire or wireless means through the use of an on-demand service, as expressly provided in Article 15(4) WPPT;

or

(b) when physical copies of the fixed performance or the phonogram are offered to the public, with the consent of the rights holder in reasonable quantity and this offering is undertaken for commercial purposes.

At the European level, Krikke explains that any 'sound recordings produced for commercial gain and any reproductions of such recordings may qualify as phono-

26. Ricketson, S. \& J. Ginsburg (2006), International Copyright and Neighbouring Rights: The Berne Convention and Beyond, New York: OUP, p. I268.

27. WPPT, Article I5(4).

28. Fiscor, M. (2002), The Law of Copyright and the Internet: The 1996 WIPO Treaties, Their Interpretation and Implementation, New York: OUP, p. 636. 
grams published for commercial purposes'. ${ }^{29}$ She goes on to state that private recordings from pre-recorded sound recordings are covered by the term, while recordings not meant to be released onto the market, such as recordings which are used for the sole purpose of repeated broadcasts of unpublished phonograms, do not qualify as published for commercial purposes. Reinbothe and von Lewinski explain that commercial phonograms can include 'all kinds of sound recordings which have been published in order to be exploited in the market place'. ${ }^{30}$ Counter-examples indicating the type of phonogram that does not give rise to the remuneration right include recordings used for the sole purpose of repeated broadcasts, unpublished recordings and recordings made by broadcasting organizations for mere documentation purposes or for distribution as a gift to friends.

The defining notions of a commercial publication, therefore, in the sense of the Rental Right Directive would seem to be those of commercial gain and exploitation in the market place. The EU Directives do not mitigate this conclusion through the inclusion of a provision equivalent to that of Article 15(4) WPPT. Nevertheless, in view of the minimum protection status of Article 8(2) Rental Right Directive, Member States are entitled to incorporate a provision similar to Article 15(4) WPPT into their national copyright framework.

Accordingly, Article 7(2) of the Dutch WNR, clarifies that, within the meaning of the first paragraph of that article, which introduces the right to equitable remuneration, a phonogram published for commercial purposes will be understood as including phonograms made available to the public. The effect of this provision is reinforced by the Explanatory Memorandum to the last amendment of the Act, which makes clear that this will be the case even if no commercial intentions underlie the act of making available. ${ }^{3 \mathrm{I}}$

Similarly, in the UK, section I82D CDPA states that the 'publication of a sound recording includes making it available to the public by electronic transmission in such a way that members of the public may access it from a place and at a time individually chosen by them'. Interpretation of the commercial character of such a publication will be dependent on the relevant provisions of UK law. According to s. $175 \mathrm{CDPA},{ }^{32}$ " "commercial publication" means (a) issuing copies of the work to the public at a time when copies made in advance of the receipt of orders are generally available to the public, or (b) making the work available to the public by

29. Krikke, J. (2006), 'Rental and Lending Right Directive', in T. Dreier \& B. Hugenholtz (eds), Concise European Copyright Law, Alphen aan den Rijn: Kluwer Law International, p. 254.

30. Reinbothe, J. \& S. van Lewinski (I993), The EC Directive on Rental and Lending Rights and on Piracy, London: Sweet \& Maxwell, p. 96.

3I. Parliamentary Report of the Dutch House of Representatives, 2007/2008, 3I 248, no. 3 (Explanatory Memorandum), p. I4.

32. The definition is included in Part I of the Act on copyright, but its application is expanded to Part II on rights in performances as well, by means of the provision of S. 2II(I). 
means of an electronic retrieval system'. Section 17 stipulates that the term 'copy' covers copies in electronic, as well as physical, form.

Replicating Article 15(4) in their national legislation is not the only route Member States have followed so as to achieve protection for a broader category of phonograms under the right to equitable remuneration. For example, the German UrhG (Copyright and Neighbouring Rights Act) grants protection over any kind of published phonogram, regardless of the purpose for which it was published, the only limitation being that, if the phonogram is used in a broadcast, it must have been lawfully recorded on an image or sound carrier that has lawfully been made available to the public. ${ }^{33}$ Similarly, in Greece the only prerequisite is that the phonogram be 'legally recorded'. ${ }^{34}$

\subsubsection{Three Possible Transmission Modes for Phonograms}

Article 8(2) of the Rental Right Directive only recognizes a right to equitable remuneration when a phonogram is 'used for broadcasting by wireless means or for any communication to the public'. By contrast, Article 3(2) of the InfoSoc Directive provides related rights holders with an exclusive right covering any 'making available to the public, by wire or wireless means, in such a way that members of the public may access them from a place and at a time individually chosen by them'. Determining, therefore, the precise acts encompassed by each of the terms 'communication to the public', 'broadcasting' and 'making available' is essential for the correct delimitation of the Articles 8(2) Rental Right Directive and 3(2) InfoSoc Directive and thereby for the accurate determination of when performers and phonogram producers will have an exclusive right and when simply a right to equitable remuneration. Of particular importance is correctly distinguishing between the two notions of 'communication to the public' and 'making available'; given that equitable remuneration is required by Article 8(2) Rental Right Directive in case of use for broadcasting and communication to the public alike, the practical implications (for the purposes of this chapter) of the accurate distinction between these two notions are fewer.

Demarcating the three rights of communication to the public, broadcasting and making available, however, is a complicated undertaking. The contours of the three shift according to the legal framework - international, European or national - within which they are examined, as well as depending on whether they are discussed within the context of copyright or related rights. As we shall see below, on both the international and European level, in the field of related rights, each of these three notions is considered to be self-standing and independent of

33. UrhG, Article 78 .

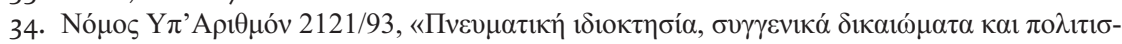

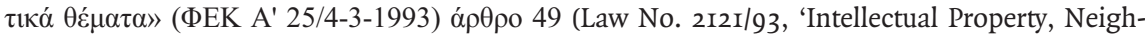

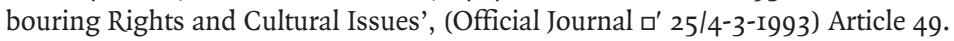


the others. By contrast, in the field of copyright, the communication right is the broader category, embracing the other two. To complicate matters further, this will not necessarily be the approach taken by national intellectual property systems. This flexibility is no accident; to the contrary, it was an integral part of the strategy followed by the Diplomatic Conference that led to the adoption of the two WIPO Internet Treaties, the intention being enabling identical results - i.e. the same type of protection for the same type of use - across the board of signatory states. In other words, the content of the rights was deemed more important than identical terminology. The same approach seems to have been followed by the European legislator as well.

Below we shall examine the history behind this complex situation. We will then try to determine the precise outline of each separate right in the international, European and national context in the area of related rights.

\subsubsection{Historical reasons for flexible terminology in related rights}

During the preparatory works for the adoption of the WIPO Internet Treaties, a consensus emerged among the participating states to the effect that the transmission of works through the use of interactive new media should indeed be the object of a new exclusive right. Nevertheless, agreement could not be reached as to the specific right that should be extended to embrace such uses, although the rights of communication to the public and distribution were identified as the two major candidates. As a result, compromise was sought in the adoption of the socalled 'umbrella solution'. ${ }^{35}$ The term refers to the neutral, legal-characterizationfree description of the act of interactive digital transmission that does not tie the hands of Contracting Parties as to the appropriate mode of transposition into national legislation, while prescribing the same effect (the granting of an exclusive right to the owners of copyright and related rights alike) for all Contracting Parties, whatever the system they choose to follow. This neutral description can be found in both the WCT and WPPT and is as follows: 'the making available to the public of their works/performances fixed in phonograms/phonograms in such a way that members of the public may access these works from a place and at a time individually chosen by them'.

In the case of the $\mathrm{WCT}^{36}$ the umbrella solution was not fully applied. Instead, the neutral description of the act of making available was incorporated into Article 8 as part of the author's exclusive right of communication to the public. The right of communication to the public in the sense of Article 8 WCT also includes

35. 'WIPO Handbook on Intellectual Property' ( $2^{\text {nd }}$ ed.), WIPO Publication No. 489 (E) 2004). Available at: www.wipo.int/about-ip/en/iprm/.

36. WIPO Copyright Treaty (adopted 20 December 1996, entered into force 6 March 2002) S. Treaty Doc. No. I05-I7 (I997) (hereafter: WCT). 
broadcasting. ${ }^{37}$ At the same time, however, it was stated in the Diplomatic Conference that Contracting Parties are free to implement the obligation to provide an exclusive making available right covering interactive transmissions through the application of a right other than that communication right or through a combination of rights. ${ }^{38}$ If the same approach had been followed during the drafting of the WPPT and the communication right had been designed as including the right of making available in the field of related rights as well, an equitable remuneration would indeed have been due for the digital interactive transmission of a fixed performance over the internet.

Within the WPPT, however, the application of the 'umbrella solution' was different. As Ficsor explains, a majority of countries were not prepared to furnish phonogram producers with exclusive rights with respect to communication to the public and broadcasting. By contrast, in the case of interactive transmissions, an exclusive right was deemed indispensable. ${ }^{39}$ As a result, in the WPPT we see what has been termed the 'fully-fledged' application of the 'umbrella solution': a self-standing exclusive 'making available' right is granted in Article io for performers and Article I4 for phonogram producers, using the neutral description of interactive digital transmissions directly. The communication right is handled separately in Article 6, where an exclusive right is provided for performers for their unfixed performances, except where the performance is already a broadcast performance, and Article 15, where a right to equitable remuneration is granted to both phonogram producers and performers. Under the WPPT, as opposed to the WCT, the division of the exclusive rights of communication to the public and making available to the public into two separate articles makes clear that the expression 'communication to the public' does not incorporate the right of making available through interactive digital transmissions. ${ }^{40}$ We therefore conclude that Article I5 WPPT establishes no right for equitable remuneration for performers and phonogram producers in the case of direct or indirect use of phonograms published for commercial purposes for their making available to the public by wire or wireless means in such a way that members of the public may access them from a place and at a time individually chosen by them. In other words, on the international level, no equitable remuneration is due for transmissions on an on-demand basis; an exclusive right being instituted for such services instead.

37. Entry on 'Broadcasting, right of ' in Fiscor, M. (2003), Guide to the Copyright and Related Rights Treaties Administered by WIPO and Glossary of Copyright and Related Rights Terms, Geneva: WIPO, p. 270.

38. WCT, Article 8.

39. Fiscor, M. (2002), The Law of Copyright and the Internet: The 1996 WIPO Treaties, Their Interpretation and Implementation, New York: OUP p. 628 and p. 629.

40. Ricketson, S. \& J. Ginsburg (2006), International Copyright and Neighbouring Rights: The Berne Convention and Beyond, New York: OUP, p. I246. 
National legislators, however, still enjoy flexibility as to the legal characterization of the exclusive making available right of performers and phonogram producers and may choose to provide it not only through the establishment of a separate right, but also through the application of another right, such as the communication right, or of a combination of rights. ${ }^{4 \mathrm{I}}$

Turning to the European situation, Article 3(2) of the InfoSoc Directive transposes into EU law the making available right of Articles io and I4 WPPT. Like the WPPT, Article 3(2) does not grant neighbouring rights holders the more general right of communication to the public, which, in conformity with the Article 8 WCT 'half-opened umbrella' approach, is offered to the holders of authors' rights in Article 3(I) of the Directive..$^{42}$ No provision corresponding to Article 6 WPPT had to be introduced in the acquis, as performers (but not phonogram producers) already benefited from an exclusive right for the communication to the public of their unfixed performances, as codified in Article 8(I) of the Rental Right Directive. ${ }^{43}$ Thus, the 'fully-fledged umbrella' approach of the WPPT has been adopted unmodified in the European copyright directives. Consequently, the term 'communication to the public', as used in Article 8(2) Rental Right Directive, should be taken to exclude the making available to the public by wire or wireless means in such a way that members of the public may gain access from a place and a time individually chosen by them. Each of the three rights, i.e. communication to the public, broadcasting and making available, are as separate from each other in the European arena as in the international one. Ergo, within the EU, the online ondemand offering of sound recordings should not be taken to give rise to a right for equitable remuneration.

This will not necessarily be the approach taken by the individual EU Member States - although, as already mentioned, given that Article 8(2) Rental Right Directive introduces a minimum protection provision, the actual content of the right may never be more limited whatever the strategy followed to introduce it. So, for example, in its UK implementation, the act of communication to the public extends to both the broadcasting and the making available to the public of the work by electronic transmission in such a way that members of the public may access it from a place and at a time individually chosen by them. This general definition applies both to works protected by copyright and to sound recordings protected

4I. Ficsor, M. (2006), 'Collective Management of Copyright and Related Rights in the Digital, Networked Environment: Voluntary, Presumption-Based, Extended, Mandatory, Possible, Inevitable?' in D. Gervais (ed.), Collective Management of Copyright and Related Rights, Alphen aan den Rijn: Kluwer Law International, p. 56.

42. Bechtold, S. (2006), 'Information Society Directive', in T. Dreier \& B. Hugenholtz (eds), Concise European Copyright Law, Alphen aan den Rijn: Kluwer Law International, p. 360.

43. Ibid., 362. 
by related rights. ${ }^{44}$ The Copyright, Designs and Patents Act instead specifically prohibits, in s.I82D, a remuneration obligation for the act of making available. The same route is taken by the Dutch legislator, who in Article 2(I)(d) of the Dutch Neighbouring Rights Act lists making available among the possible forms of expression that the act of communication to the public can take. Article 7(I) then grants the producer or performer a right to equitable remuneration when a phonogram is 'broadcast or otherwise communicated to the public', but specifies that its provisions do not apply to the making available of phonograms to the public.

On the basis of the above analysis, the following pertinent question arises: what types of transmission correspond to which of these three separate - in the case of related rights - legal constructions of the right of communication to the public, the broadcasting right and the right of making available to the public? If, according to the EU Directives, equitable remuneration is paid when a phonogram is broadcast or communicated to the public, but an exclusive right is granted when it is made available to the public, which specific acts of (digital or analogue) delivery do each of these terms encompass and where do the boundaries between them lie? In other words, for precisely what use is remuneration owed and for what is an exclusive right granted? Above we explained the legal terminology employed in the area of related rights in phonograms and the relationship between the three terms on three different levels of legal hierarchy. Below we will examine the acts that these terms qualify. Particularly in view of the flexibility granted under the umbrella solution to national legislators as to the legal characterization of acts of dissemination, ascertaining the precise content hidden behind often varying solutions and terminology gathers special significance.

\subsubsection{Broadcasting by wireless means}

According to the definition provided by the Rome Convention, "broadcasting' means the transmission by wireless means for public reception of sounds or of images and sounds' ${ }^{45}$ The more recent WPPT gives a more up-to-date definition, in the main part inherited from the Rome Convention: "broadcasting' means the transmission by wireless means for public reception of sounds or of images and sounds or of the representations thereof. The WPPT also differs from the Rome Convention ${ }^{46}$ in that it includes 'rebroadcasting' within the concept of 'broadcast-

44. CDPA 1988, ss. 20, I82D, 2II; See also Bently, L. \& B. Sherman (2004), Intellectual Property Law, Oxford: OUP, p. I44.

45. Rome Convention, Article 3(f).

46. The Rome Convention defines rebroadcasting as 'the simultaneous broadcasting by one broadcasting organization of the broadcast of another broadcasting organization'. 
ing' ${ }^{47}$ In the Rome Convention, rebroadcasting is afforded its own separate definition as 'the simultaneous broadcasting by one broadcasting organization of the broadcast of another broadcasting organization'. Given that rebroadcasting is not specifically mentioned in Article $\mathrm{I} 2$ of the Rome Convention, no right to equitable remuneration thus arises under the Rome Convention when a phonogram is rebroadcast. To the contrary, rebroadcasting will be protected with a right to equitable remuneration under the WPPT. The WPPT also makes explicit that transmission by satellite should be encompassed by the term, as should encrypted satellite broadcasting 'where the means for decrypting are provided to the public by the broadcasting organization or with its consent'. ${ }^{8}$

Given this definition, it follows that broadcasting in the WIPO sense covers both terrestrial and satellite analogue transmissions. Online/internet transmissions on the other hand, as well as cablecasting, are excluded by dint of their wired nature. ${ }^{49}$ Digital terrestrial and satellite services are covered by the term, as such transmissions take place on radio frequencies through the airways.

Finally, it is worth pointing out that the phrase 'public reception', used in the definitions of both the Rome Convention and the WPPT, is not entirely accurate. The expression would seem to suggest that the act of reception must take place in the presence of a group of people corresponding to the public or, at least, at a place open to the public. Yet, as commentators have observed, there is no indication in the records of the 196r Rome Diplomatic Conference that this was indeed the intended meaning..$^{50}$ The wording should therefore be accepted as a drafting error and the definition taken to correspond to that of the Berne Convention, i.e. 'a communication to the public by any means of wireless diffusion of signs, sounds or images' ${ }^{5 \mathrm{I}}$ Indeed, as mentioned above, the basic nature of broadcasting is generally taken to be that of a method of communication to the public, despite the fact that specifically in the area of related rights and in the international context, broadcasting is held apart as a separate category in its own right, rather than a subspecies of a broader concept.

The question that then comes to the fore is what precisely is meant by reference to 'the public'. No express definition is provided by the WIPO-administered trea-

47. Fiscor, M. (2003), Guide to the Copyright and Related Rights Treaties Administered by WIPO and Glossary of Copyright and Related Rights Terms, Geneva: WIPO, p. 236; Fiscor, M. (2002), The Law of Copyright and the Internet: The 1996 WIPO Treaties, Their Interpretation and Implementation, New York: OUP, p. 636 .

48. WPPT, Article 2(f).

49. See also WIPO Standing Committee on Copyright and Related Rights, 'The WIPO Treaty on the Protection of Broadcasting Organizations' ( $17^{\text {th }}$ Session, Geneva, 3 to 7 November 2008).

50. Fiscor, M. (2003), op. cit., p. 236.

51. Berne Convention for the Protection of Literary and Artistic Works (adopted 9 September I886, came into force 5 December I887) S. Treaty Doc. No. 99-27, as amended, (hereafter: Berne Convention) Article Irbis(I). 
ties, but the WIPO Glossary does explain that "the public' is a group consisting of a substantial number of persons outside the normal circle of a family and its closest social acquaintances'. It is not relevant whether the members of the public are all gathered in one location or the reception can occur in multiple different places and times. Legal scholars also point out that 'any group comprising the 'non public' (for example, the traditional 'family circle') should be economically insignificant'. ${ }^{52}$ In any case, the nature of broadcasting itself is such that diffusion will always take place among a wide audience, rendering a precise definition of 'the public' a mute point. As will be seen below (section 2.3.3), that is not necessarily so with the rights of communication to the public and making available to the public.

No harmonized definition of broadcasting as an act restricted by copyright and related rights exists within the European acquis. Instead interpretation is left to the individual courts and legislators of the Member States. ${ }^{53}$ Nevertheless, it would seem that, in the EU, the term broadcasting is broader than that given by the WIPO Treaties, as is indicated by its express limitation to wireless means in Article 8(2) of the Rental Right Directive. ${ }^{54}$ The term 'broadcasting by wireless means', therefore, in the sense of the Rental Right Directive, should be taken to correspond to the term 'broadcasting' in the Rome Convention, covering all digital and analogue wireless transmissions, whether terrestrial or satellite. ${ }^{55}$

According to the Rental Right Directive, the equitable remuneration right will arise both for indirect and direct uses of a phonogram for broadcasting. ${ }^{56}$ Direct use of a phonogram for broadcasting refers to the case where a broadcast is made

52. Ginsburg, J. (2004), 'The (New?) Right of Making Available to the Public?', in D. Vaver \& L. Bently, Intellectual Property in the New Millennium, Cambridge: Cambridge University Press, p. 236.

53. Hugenholtz, P. B., et. al (2006), 'The Recasting of Copyright and Related Rights for the Knowledge Economy' Amsterdam: Institute for Information Law. Available at: www.ivir.nl/publications/other/IViR_Recast_Final_Report_2006.pdf.

54. The AVMS Directive reinforces this perception by including no reference to wireless means in its definition of 'television broadcasting' as 'an audiovisual media service provided by a media service provider for simultaneous viewing of programmes on the basis of a programme schedule'. See: Directive 2007/65/EC of the European Parliament and of the Council of II December 2007 amending Council Directive 89/552/EEC on the coordination of certain provisions laid down by law, regulation or administrative action in Member States concerning the pursuit of television broadcasting activities [2007] OJ L 332/27 (hereafter: AVMS Directive).

55. The inclusion of satellite broadcasting in the term 'broadcasting by wireless means' within the meaning of the Rental Right Directive is confirmed by Article 4(2) of the SatCab Directive (Council Directive 93/83/EEC of 27 September 1993 on the coordination of certain rules concerning copyright and rights related to copyright applicable to satellite broadcasting and cable retransmission, [I993] OJ L248/I5).

56. The Rome Convention limits application to direct uses alone. The WPPT expands application to indirect uses explicitly. In the case of the Rental Right Directive this expansion is implied, as the Member States thought it unnecessary to make explicit the inclusion of both forms. 
directly on the basis of a phonogram. Indirect use refers to the case where a phonogram is used for a broadcast which is subsequently rebroadcast by another broadcasting organization. ${ }^{57}$

The notion of 'public' is likewise not defined by the EU Directives, although the European Court of Justice (ECJ) has dealt with the question in a series of case law. In 'Lagardère Active Broadcast', ${ }^{58}$ the Court stated that in the context of a communication to the public by satellite, 'the public' will consist of "an indeterminate number of potential listeners". Given that "communication to the public by satellite' should be taken to be a form of broadcasting and given moreover that this interpretation is in line with other Court rulings dealing with audiovisual broadcasting ('Mediakabel'59) and communication to the public ('SGAE' ${ }^{60}$ ), we can comfortably assume that in relation to broadcasting in a general sense the concept of 'the public' would be defined by the ECJ in an identical manner.

In any case, given the absence of a harmonized EU definition of broadcasting, national law takes centre stage. Article I (g) of the Dutch Neighbouring Rights Act gives a very technical definition of broadcasting as 'the distribution of programmes by means of a transmitter [...] or a broadcasting network'. The terms 'transmitter' and 'broadcasting network' are further defined in sections of the Media Law and Telecommunications Law. ${ }^{6 \mathrm{r}}$ As for the notion of 'the public', in Article $\mathrm{I}$, in relation to the right of communication to the public, it is noted that this includes 'a restricted circle, except where this is confined to relatives, friends or equivalent persons and no form of payment whatsoever is made for attendance'. ${ }^{62}$ Uncertainty exists as to whether rebroadcasting is covered by the Dutch provisions on the right to equitable remuneration: the Act provides a separate definition for rebroadcasting than that given to broadcasting in Article $\mathrm{I}(\mathrm{h})$, but no mention of rebroadcasting is made by Article 7 on the right to equitable remuneration.

In the UK, the CDPA defines broadcasting as 'an electronic transmission of visual images, sounds or other information which (a) is transmitted for simultaneous reception by members of the public and is capable of being lawfully received by them, or (b) is transmitted at a time determined solely by the person making the

57. Reinbothe, J. \& S. van Lewinski (1993), The EC Directive on Rental and Lending Rights and on Piracy, London: Sweet \& Maxwell, p. 97.

58. Case C-I92/04 Lagardère Active Broadcast $v$ SPRE, GVL \& CERT (ECJ I4 July 2005).

59. Case C-306/05 Sociedad General de Autores y Editores de España (SGAE) v Rafael Hoteles SA (ECJ 7 December 2006).

6o. Case C-89/04 Mediakabel BV v Commissariaat voor de Media (ECJ 2 June 2005).

6r. Mediawet, Article I, subsections o and q and Telecommunicatiewet, Article I.I, subsections e and ii.

62. WNR, Article 2(7). 
transmission for presentation to members of the public'. ${ }^{63}$ This definition encompasses digital, analogue, terrestrial and satellite transmissions. Internet transmissions are expressly excluded. Encrypted transmissions are included if they may be received by subscribers who have received a decoder. ${ }^{64}$

\subsubsection{Making available to the public}

Articles Io and I4 WPPT first introduced the right of making available in the international legal scene. They establish that the right covers 'the making available to the public [...] by wire or wireless means, in such a way that members of the public may access them from a place and at a time individually chosen by them'. No definition of the making available right exists in the Rome Convention.

Article 3(2) of the InfoSoc Directive adopts the exact same definition as that of the WPPT. On this basis, according to Bechtold, ${ }^{65}$ the characteristic features of the making available right are:

(a) The making available of the work, i.e. the act of providing the work to the public. The user's subsequent retrieval of the work is irrelevant for the application of the right; the exclusive right exists irrespective of whether and in what manner the work is actually accessed;

(b) The limitation of the right to making works available to the public (see above, section 2.3.2);

(c) The possibility for members of the public to access the work at a time and from a place individually chosen by them, i.e. through the means of an interactive, on-demand ${ }^{66}$ service. $^{67}$

We therefore conclude that, on the EU level, the provision of a sound recording to the public through interactive, on-demand services leads to the application of the exclusive right of making available and does not constitute communication to the public. In the opposite case, when the service is linear and no such individual

63. CDPA, s. 6(I).

64. Bently, L. \& B. Sherman (2004), Intellectual Property Law, Oxford: OUP, p. I44.

65. Bechtold, S. (2006), 'Information Society Directive', in T. Dreier \& B. Hugenholtz (eds.), Concise European Copyright Law, Alphen aan den Rijn: Kluwer Law International, p. 36r.

66. The Oxford English Dictionary defines the expression 'on-demand' as something 'done or available when required or requested; providing or requiring a commodity, service, etc.', when required or requested. However, in the copyright and related rights context it is important to remember that, as the WIPO Glossary of Copyright and Related Rights Terms (see above ft.22) explains, the term will often be used as 'a synonym of making available to the public in the sense in which that term is used in the provision on the right of making available to the public'.

67. See Commission Recommendation of 18 May 2005 on collective cross-border management of copyright and related rights for legitimate online music services [2005] OJ L 276/54 (hereafter: Online Music Recommendation, Recital (f)(iii). 
control is offered to the user, the possible application of the communication right should instead be investigated.

The WPPT definition of 'making available' has also been incorporated virtually unchanged into the national law of the Contracting States. For example, in the Netherlands, the right is defined as the 'making material protected [by the Dutch Neighbouring Rights Act] available to the public by means of wired or wireless connection in such a manner that they have access to it at such time and place as they might individually select'. ${ }^{68}$ In the UK, the right is defined as the making 'available to the public [...] by electronic transmission in such a way that members of the public may access the recording from a place and at a time individually chosen by them'. ${ }^{69}$

\subsubsection{Communication to the public}

According to Article 2(g) WPPT, the communication to the public of a performance or a phonogram means 'the transmission to the public by any medium, otherwise than by broadcasting, of sounds of a performance or the sounds or the representations of sounds fixed in a phonogram'. No definition of the right exists in the Rome Convention. Masouyé, in his analysis of the Convention, crisply outlines the right as the transmission of a phonogram 'by loudspeakers or by wire'. ${ }^{70}$ It should be noted from the outset that, on the international level, the WPPT and the Rome Convention direct, in the area of related rights, the term away from the meaning that has been assigned to it in the context of copyright, as governed by the WCT and the Berne Convention. To be specific, in related rights:

(a) The making available right is not included within the scope of the communication right (see above section 2.3.I).

(b) Broadcasting is likewise not included within the scope of the communication right - in fact it is explicitly excluded by Article 2(g) itself.

(c) Instead, local communication to the public, i.e. communication in the presence of the public or at a place open to the public through some technical means or process, is included..$^{7}$

68. WNR, Article $\mathrm{I}(\mathrm{m})$.

69. CDPA, s. I82CA.

70. Masouyé, C. (I98I), Guide to the Rome Convention and to the Phonograms Convention, Geneva: WIPO, p. 36 .

7I. Entry on 'communication to the public, right of ', in Fiscor, M. (2003), Guide to the Copyright and Related Rights Treaties Administered by WIPO and Glossary of Copyright and Related Rights Terms, Geneva: WIPO, p. 275 . 
In the case of copyright, local communication would normally qualify as the separate exclusive right of public performance, recitation or display. ${ }^{72}$ However, the very nature of rights in fixed performances and phonograms means that even local communication to the public will by definition always be conducted through technical means, making the distinction between public performance and communication to the public redundant. Nevertheless, it is important to keep this disparity in mind, especially when analysing the language used in national law, where the relevant terms often carry slightly different meanings.

In any case, the important thing to take away from the definition of Article 2(g) WPPT is that the provision of a sound recording to the public through any medium will constitute communication to the public, as long as it is not through either broadcasting (which gives rise to a right to equitable remuneration anyway of its own right) or on-demand services (which will provide the right-holder with an exclusive making available right instead). Among others, this means that the communication right is seen as covering cable transmissions, ${ }^{73}$ online transmissions, as well as the playing of the phonogram in a public place, as for example in a restaurant, bar, pub, etc.

On the European level, Recital 23 of the InfoSoc Directive states that communication to the public 'should be understood in a broad sense covering all communication to the public not present at the place where the communication originates'. This will include, according to Bechtold, transmission of a public performance via technical means, e.g. to an audience in an adjacent room. ${ }^{74}$ In the field of related rights, as governed by the Rental Right Directive, similar to what happens on the international level and in compliance with the "fully-fledged umbrella' approach analysed above, communication to the public refers to the playing a phonogram to the public by any medium other than broadcasting and in a non-on-demand manner.

As with broadcasting, it should be noted that, within the meaning of the Rental Right Directive, such use may be made either directly or indirectly. Direct use refers to the situation in which a phonogram is played directly in a public place, such as a restaurant, supermarket or department store, while indirect use refers to the use of a phonogram, e.g. for a radio broadcast which is then played in a public place. ${ }^{75}$

Finally, the definition of public, both in the case of the communication and the making available right, will be the same as under 'broadcasting' (see above, sec-

72. Berne Convention, Article II(I)(i) and IIter(I)(i).

73. Entry on 'cablecasting' in Fiscor, M., op. cit, p. 271.

74. Bechtold, S. (2006), 'Information Society Directive' in T. Dreier \& B. Hugenholtz (eds.), Concise European Copyright Law, Alphen aan den Rijn: Kluwer Law International, p. 360.

75. Reinbothe, J. \& S. van Lewinski (1993), The EC Directive on Rental and Lending Rights and on Piracy, London: Sweet \& Maxwell, p. 97. 
tion 2.3.2). As opposed to broadcasting, however, given that communication of a sound recording to a small group of people is possible (e.g. playing a $\mathrm{CD}$ at a family gathering), as is its making available (e.g. sending an email containing audio files in attachment to a friend or posting it on a MySpace profile) the precise openness or closeness of the definition becomes far more critical.

Member States to the EU boast individual definitions of the term 'communication to the public' that do not conform with the meaning appointed to it in the European acquis. ${ }^{76}$ In the Netherlands, no definitive demarcation of the communication right is provided by the Neighbouring Rights Act, although Article 2(I) (d) does specify that the broadcasting, rebroadcasting and making available to the public of a phonogram are, among others, covered by the term. ${ }^{77}$ Visser gives an indication of what such other forms might be by explaining that the communication right would also cover playing a phonogram in a public place, such as a café or a department store. ${ }^{78}$ The Dutch definition of communication to the public in the area of related rights seems, therefore, to be close to the definition assigned to the term in the copyright context on the European and international level. Dutch legislation compensates for this expansive definition by providing that equitable remuneration is due when a phonogram is broadcast, rebroadcast or communicated to the public, otherwise than by being made available to the public, thus neatly aligning Article 7 WNR with Article 8(2) of the Rental Right Directive.

In the UK, communication to the public is defined by s. 20 CDPA as 'communication to the public by electronic transmission, and in relation to a work [the term includes] (a) the broadcasting of the work; (b) the making available to the public of the work by electronic transmission in such a way that members of the public may access it from a place and at a time individually chosen by them' ${ }^{79}$ As opposed to the extraordinarily broad Dutch definition of communication to the public, therefore, in the UK in the area of related rights the right of communication to the public is more circumscribed than under European law, as it does not extend to other methods of transmission to a public not present at the place where the communication originates. For this reason, s. I82D CDPA also stipulates that a right to equitable remuneration is due to performers when their sound recording is not only communicated to the public in a way other than by being made available to the public, but also when it is played in public.

76. See above, Part I, Section 3.I, for an analysis of the reasons behind this situation.

77. WNR, Article 2(I)(d).

78. Visser, D.J.D. (I999), Naburige Rechten : van Uitvoerende Kunstenaars, Fonogrammenproducenten, Filmproducenten en Omroeporganisaties, Deventer: W.E.J. Tjeenk Willink, p. 74.

79. CDPA, ss. 20. The definition is included in Part I of the Act on copyright, but its application is expanded to Part II on rights in performances as well, by means of the provision of s. 2II (I). 


\subsubsection{Correctly allocating specific acts to the correct right}

In practical terms, what type of service will be an on-demand one and what not? The Online Music Recommendation of $2005^{80}$ gives us an indication as to what types of technology fall into which category. According to Recital (f)(ii), the right of communication to the public of a musical work, for which equitable remuneration must be paid, includes webcasting, internet radio, simulcasting and near-ondemand services received either on a personal computer or on a mobile telephone. Below, each one of these activities will be separately examined. It should be noted in advance that no fast-and-steady legal definition of any of these terms currently exists. The concepts and uses to which the technology can be put are still evolving.

The analysis below will only attempt to deduce the meaning of the terms within the EU context.

\section{Webcasting}

According to the Oxford English Dictionary, webcasting is 'broadcasting over the Internet, esp. the transmission of a video signal that is viewable in real time by multiple users of a web site; (also) the action or practice of disseminating information over the Internet using push technology', while a webcast is a 'live broadcast transmitted over the Internet'. A webcast is therefore seen as a mechanism for the 'pushing' of content to the consumer, rather than the 'pulling' of content from a viewer that has actively sought it out. ${ }^{8 \mathrm{I}}$ The reference to push technology, the comparison with broadcasting, as well as the use of the words 'real time' and 'live' in the OED entry would all seem to suggest that webcasting is indeed, as stated in the Commission's Recommendation, not an interactive, on-demand service.

Similarly, Wikipedia explains that '[e]ssentially, webcasting is 'broadcasting' over the Internet, through the use of streaming media technology. The generally accepted use of the term webcast is the "transmission of linear audio or video content over the Internet". 'Linear' is an expression usually used as the opposite of on-demand, ${ }^{82}$ further giving credence to the view that webcasting qualifies as communication of content to the public, rather than its making available, and does give rise to a right to equitable remuneration for the phonogram producer and the performer.

Nevertheless, confusion seems to still exist as to the communication to the public credentials of webcasting as a form of content distribution. References

8o. Online Music Services Recommendation, see $\mathrm{ft} 7 \mathrm{I}$.

8I. Gillies, L.E. \& A. Morrison (2002), 'Securing Webcast Content in the European Union: Copyright, Technical Protection and Problems of Jurisdiction on the Internet', E.I.P. R. 24(2):74.

82. See AVMS Directive, Article I(e) and (g). 
have been made in the past to 'on-demand webcasting' by legal scholars, ${ }^{83}$ while Wikipedia also obscures matters by, on the one hand, classifying webcasting as a 'non-interactive', 'linear' dissemination method and, on the other hand, stating that a 'webcast may either be distributed live or on demand'. The entry on webcasting in the WIPO Glossary is neutral, inconclusively defining webcasting as the 'making accessible for reception by the public of transmissions of sounds, images, or sounds and images or the representations thereof, by wire or wireless means over a computer network. Such transmissions, when encrypted, are supposed to be considered as 'webcasting' where the means for decrypting are provided to the public by the webcasting organization or with its consent'. ${ }^{8}$ It is the author's opinion that the non-on-demand status of webcasting as a service cannot be influenced by the time-shifting possibilities offered by devices, such as personal media players or digital video recorders (DVRs), with the help of which content may be downloaded for viewing at a later time of the consumer's choice. To claim that such capabilities transform webcasting into an on-demand service would be tantamount to claiming that traditional TV broadcasting is also an on-demand service, because it may be recorded onto tape and viewed at any later time through the use of a VCR. Webcasting should also not be confused with online music or video sharing platforms, such as YouTube or MTVMusic.com. Nevertheless, if, as the dust settles on the evolving concepts of new media, webcasting does emerge as a malleable term, capable of accommodating both on-demand and linear services, then it should be only the latter category that should be allowed to be included within the scope of the right of communication to the public and only for that should a right to equitable remuneration be afforded to performers and phonogram producers.

Internet radio

Internet radio is, in essence, audio webcasting, in other words the internet equivalent of conventional radio broadcasting. Being a subspecies of webcasting, it too involves the use of streaming technology, so that audio files are presented to the listener in the form of a continuous 'stream' over which he has little or no control. ${ }^{85}$ As such, internet radio must also be denied on-demand status. Like webcasting, internet radio also constitutes a communication of sound recordings to the public, rather than their making available to the public, and does generate an Article8(2) right to equitable remuneration.

83. Gillies, L.E. \& A. Morrison (2002), op. cit. p. 74; see also Wikipedia entry for 'webcast' Available at: http://en.wikipedia.org/wiki/Webcasting.

84. Entry on 'webcasting' in Fiscor, M. (2003), Guide to the Copyright and Related Rights Treaties Administered by WIPO and Glossary of Copyright and Related Rights Terms, Geneva: WIPO.

85. Wikipedia, 'Internet Radio'. Available at: http://en.wikipedia.org/wiki/Internet_radio. 


\section{Simulcasting}

According to the European Commission's 2005 Working Document Study on a Community Initiative on the Cross-Border Collective Management of Copyright, 'simulcasting' is a portmanteau for 'simultaneous broadcasting'. The term refers to 'programs or events broadcast across more than one medium at the same time ${ }^{, 86}$ or across more than one service on the same medium. ${ }^{87}$ Narrower definitions have also been put forth: in the earlier Commission IFPI decision simulcasting was defined by the notifying parties as 'the simultaneous transmission by radio and TV stations via the Internet of sound recordings included in their broadcasts or radio and/or TV signals, ${ }^{88}$ It should be noted however that the restriction of the term exclusively to internet transmissions is probably too strict and does not seem to be generally accepted. ${ }^{89}$

In any case, the allocation of simulcasting to the broader categories of 'broadcasting' or 'communication to the public' will logically depend on the medium used for the simultaneous transmission. If the content is indeed 'simultaneously broadcast' then the simulcasting should be classified as broadcasting. If any other technology is utilized, the simulcasting will constitute communication to the public. In any case, the inherent timing limitations exclude categorisation as an ondemand service (the re-transmission must be simultaneous, with the consumer offered no control). As a result, within the EU, simulcasting will always generate an equitable remuneration right under Article 8(2) of the Rental Right Directive.

\section{Near-on-demand services}

The notion of near-on-demand services has not been specifically defined in Community law. That being said, the ECJ 'Mediakabel' case $e^{90}$ does deal with the concept of 'near-video-on-demand'. In that judgement, the Court reached the conclusion that near-video-on-demand ${ }^{9 \mathrm{I}}$ is not a 'communication service operating on individual demand'. By analogous application to near-on-demand services in gen-

86. European Commission's Staff Working Document Study on a Community Initiative on the Cross-Border Collective Management of Copyright (Brussels, 7 July 2005).

87. Wikipedia, 'Simulcasting'. Available at: http://en.wikipedia.org/wiki/Simulcasting.

88. Commission Decision of 8 October 2002 relating to a proceeding under Article 8I of the EC Treaty and Article 53 of the EEA Agreement (Case No COMP/C2/38.or4 - IFPI 'Simulcasting') OJ L I07/58.

89. See Oxford English Dictionary entry on 'simulcast'.

90. Case C-89/04 Mediakabel BV v Commissariaat voor de Media (ECJ 2 June 2005).

9I. In this case, the 'near-video-on-demand' service was one that permitted users to order films from a predetermined catalogue and then, after payment of a fee and through use of a personal identification code, receive an individual key by means of which viewing the selected films at the times indicated in the service's program guide was enabled. 
eral, we reach the conclusion that they do not fall within the category of 'making available', but to the contrary constitute a method of communication to the public.

No other clarification is provided by EU legislation or case law. However, an indication of the nature of near-on-demand services can be derived from the WIPO Glossary, which, in the context of the WIPO Treaties, defines a near-ondemand service as 'a transmission of works and objects of related rights [...] in the form of broadcasting and cablecasting whose impact is the same as, or very close to, that of an on-demand transmission, without fully corresponding to the concept of the latter, such as certain subscription systems, through which entire digital-quality repertoires of authors, performers and producers of phonograms are delivered in a systematic way'. ${ }^{92}$ This would indicate - as in fact does the very term itself - that near-on-demand services are not actual on-demand services as such and that, therefore, they must either fall within the scope of broadcasting or of communication to the public. As with simulcasting, which of these two terms will be the appropriate one will depend on the technology put to use: if a near-ondemand service is transmitted as a broadcast, that will be the category to which it should be assigned. Cablecasting would indicate communication to the public. And, although the WIPO definition only offers these two possibilities, there is arguably no reason to limit possible transmission methods so severely - in fact, the notes from the WIPO Diplomatic Conference state that "[near-on-demand services] can be established by using cable or wire networks or by wireless means' ${ }^{93}$ In any case, equitable remuneration will always be due to the phonogram producer and performer.

In the international realm, it is worth pointing out that the question of near-ondemand services caused considerable debate in the run-up to the adoption of the WPPT. Initially, the Basic Proposal included a clause excluding 'any broadcasting or any communication by wire or wireless means which can only be received on the basis of subscription and against payment of a fee' from the possibility of reservation from the application of the provisions of Article 15. This would have made the right to equitable remuneration obligatory for all signatories in the special case of near-on-demand services. Certain delegations posited however that even a compulsory equitable remuneration right would not be sufficient and suggested enabling countries to derogate from this provision through the establishment of an exclusive right for near-on-demand services. These suggestions were

92. Entry on 'near-on-demand transmission', in Fiscor, M. (2003), Guide to the Copyright and Related Rights Treaties Administered by WIPO and Glossary of Copyright and Related Rights Terms, Geneva: WIPO, p. 297. For reasons of comparison, see also US Copyright Act, Pub. L. No. 94-553, 9o Stat. 254I (I976) s. II4 (j)(8) and (II).

93. Fiscor, M. (2002), The Law of Copyright and the Internet: The 1996 WIPO Treaties, Their Interpretation and Implementation, New York: OUP, p. 245. 
justified precisely by noting the considerable similarities between on-demand and near-on-demand. ${ }^{94}$ In the event, the final conclusion of the controversy was the adoption of Agreed Statement 12, which accompanies the Article and states that its content 'does not represent a complete resolution of the level of rights of broadcasting and communication to the public that should be enjoyed by performers and phonogram producers in the digital age'. The discussion at the conference confirms that near-on-demand services will normally fall within the ambit of Article I5 WPPT and that equitable remuneration is due, according to the provisions of the WPPT, for the use of a phonogram in this way.

\section{On-demand services}

If webcasting, simulcasting, internet radio and near-on-demand services all fall within the realm of communication to the public, which modes of delivery of digital content unequivocally do generate an exclusive making available right along the lines of Article 3(2) of the InfoSoc Directive? Video-on-demand services, as well as online video sharing services, such as YouTube, will certainly qualify. ${ }^{95}$ On-demand radio will also definitely be encompassed. Likewise, peer-to-peer downloading websites, like the Pirate Bay, and online digital media stores, such as the iTunes store, will also be caught by the definition of on-demand services.

An interesting case is presented by podcasting. Podcasts are defined in a recent European working document as 'programmes, recorded as digital audio files, which are downloadable and transferable to portable digital devices such as $\mathrm{MP}_{3}$ players' ${ }^{96}$ Although the end-user must employ special client software applications ('podcatchers') to download podcast files, these automatically identify and retrieve new files uploaded to a web feed to which the user has previously subscribed. These two elements of subscription to episodically released series and automated download arguably bring podcasts within the ambit of near-on-demand subscription services and therefore the right of communication to the pub-

94. Ibid., p. 245 and p. 639.

95. It should be noted that, as opposed to the right of equitable remuneration, for which, as noted above (Part I, Section I), only four EU Member States (Belgium, Croatia, Germany and Spain) have extended the minimum protection provision of Article 8(2) Rental Right Directive to encompass audiovisual fixations, the exclusive making available right is granted to the holders of related rights for all types of fixations, including audiovisual fixations, already on the European level by means of Article 3(2) InfoSoc Directive. See also Vanheusden, E. (2007), 'Performers' Rights in European Legislation: Situation and Elements for Improvement' (AEPO-ARTIS). Available at: www.aepo-artis.org/usr/AEPO-ARTIS\%20Studies/Study\%20Performers\%2oRights \%20in\%2oAcquis_AEPO-ARTIS.pdf.

96. For a definition of podcasting, see 'Commission Staff Working Document Accompanying the Communication from the Commission to the European Parliament, the Council, the European Economic and Social Committee and the Committee of the Regions on Creative Content Online in the Single Market' $\{\operatorname{COM}(2007) 836$ final $\}$, Brussels, 3 January 2008, SEC(2007) I710. 
lic, yet at the same time it is hard to view what is, in actual fact, no more than a sophisticated variant of run-of-the-mill downloading as non-on-demand. The decisive factor in determining whether podcasting constitutes an on-demand service or a communication to the public will be the moment at which it is considered that the user gains access to the material: once the download is complete, the user can individually choose the time at which she wishes to open and listen to, i.e. to 'pull', the file. However, in contrast to regular downloading services, the precise moment at which that download will take place does not depend on the user and may not happen for weeks or months after subscription, if at all: subscription does not necessarily result in immediate access, as the content still has to be 'pushed' unilaterally to the subscribing public by the instigating podcaster. Furthermore, full control is not available to the isolated user as to what material will appear on her audio player: she is limited to what will be allocated the next slot in the podcast series by the distributor. It would therefore seem that elements of both on-demand and linear services are existent in podcasting, placing this dissemination method midway between the two acts of making available and communication to the public. ${ }^{97}$

Matters are further complicated by the versatility of podcasting platforms: in addition to the possibility of subscription to future podcasts, podcasting services frequently also offer the user immediate access (by means of either downloading or streaming) to old podcast episodes in the podcaster's archives on a file-by-file basis. The author, however, would argue that a distinction should be drawn between the different options open in parallel to each other on a single multi-tasking platform, with the actual act of podcasting itself (a subscription service) receiving separate legal treatment to that reserved for downloading and streaming, which are (undisputed) acts of making available. What the legal status of podcasting is and whether equitable remuneration should be paid by the user engaging in podcasting remains an open and pertinent question. In any case, podcasting is a prime illustration of the fact that, as others have noted before, the dichotomy set up by legislators between 'linear' and 'non-linear' services is a false one; elements of both 'push' and 'pull' technologies will exist in most methods of distributing content and attempts to draw a decisive line between the two will ultimately prove futile..$^{8}$

97. Hugenholtz, B. et. al (2006), 'The Recasting of Copyright and Related Rights for the Knowledge Economy', The Hague: Institute for Information Law. Available at: www.ivir.nl/publications/other/IViR_Recast_Final_Report_2006.pdf, 57.

98. Ginsburg, J. (2004), 'The (New?) Right of Making Available to the Public?', in D. Vaver \& L. Bently, Intellectual Property in the New Millennium, Cambridge: Cambridge University Press, p. 236; Reinbothe, J. \& S. von Lewinski (2002), 'The WIPO Treaties I996: Ready to Come into Force', European Intellectual Property Review 24(4): IIo. 
We therefore conclude that the Commission's Recommendation is completely accurate: webcasting, simulcasting, internet radio and near-on-demand services all fall within the ambit of the right of communication to the public and not the making available right. Use of a commercial phonogram in any of these ways will consequently activate Article 8(2) Rental Right Directive and the performer and phonogram producer's right to equitable remuneration will be brought into play.

\subsection{Collective Management of the Right to Equitable Remuneration}

\subsubsection{Three License Schemes for Collective Rights Management}

Article 8(2) Rental Right Directive explains that the user owes the performer and phonogram producer equitable remuneration and that this must be shared between the two recipients, but provides no further specifications. The Member States are accordingly free to choose between any of the three following methods of implementation:

(a) The payment may be made to performers and producers jointly (this is the case, e.g. in the Netherlands);

(b) The payment may be made to performers, who then have an obligation to pay a share of the remuneration to the phonogram producers (this is the case, e.g. in Germany); or

(c) The payment may be made to producers, who then have an obligation to pay a share of the remuneration to the performers (this is the case, e.g. in the UK). ${ }^{99}$

In practice, the collection and distribution of remuneration fees is usually undertaken by collective management organizations representing either or both of the two categories of right-holders. The mode of function of these organizations will depend on the source from which they draw their mandate. In most European countries, one of the following three systems applies:

(a) Collective management of the right is compulsory by operation of law, thereby in essence establishing a system of non-waivable compulsory licensing. Under this arrangement, the rights holder is vested with a right to equitable remuneration regardless of his intent; waiver is not possible, while the collection of monies is by law exclusively assigned to one or more collective

99. Reinbothe, J. \& S. van Lewinski (1993), The EC Directive on Rental and Lending Rights and on Piracy, London: Sweet \& Maxwell, p. 98. 
management organizations (as we shall see, this is generally accepted to be the case in the Netherlands, although this view can be challenged);

(b) Collective management is not actually compulsory by law; instead, either a waivable compulsory license scheme or a voluntary license scheme is in place. Under the first system, collection of equitable remuneration is entrusted to one or more collective management organizations, but an opt-out possibility is offered: waiver of the right, thus resulting in inability of the relevant collective management society to collect in the name of the rights holder, is possible. The second system is an opt-in one: equitable remuneration will only be collected if the rights holder has chosen to require it (this is the case in the UK). It should be noted that, as is explained in detail below, even where a waivable compulsory licensing system or a voluntary licensing system are in place, collective management will in all likelihood still remain an irrefutable reality offering rights holders and users very little room for manoeuvre: royalties will usually be collected through the blunt tool of blanket licenses for the use of a vast repertory managed by societies that function as de facto, if not actual, monopolies.

All three of these possible collective rights management schemes are compatible with Creative Commons licenses, the distinction is significant, however, as explained in the Introduction, depending on the system in operation, the Creative Commons licensing suite sets different consequences in train for the attachment of a license to a phonogram: in the case of non-waivable compulsory license schemes, CC licenses establish that the licensor reserves the right to collect royalties for the exercise of the rights granted under the license, while if a waivable compulsory license scheme or a voluntary license scheme are in place, the CC licenses state that the licensor waives this right.

Is the establishment of a waivable compulsory license scheme or a voluntary license scheme possible according to the relevant international and European legal frameworks? On the international level, no specification is made as to the possibility of waiver on the part of the performer and phonogram producer of the right to equitable remuneration. Within the EU's Rental Right Directive the permissibility of such waiver can be deduced a contrario by comparison with the right to equitable remuneration for the rental of a phonogram, the unwaivable status of which is expressly declared in the very title of Article 5 Rental Right Directive. No such qualification is introduced in relation to the right of Article 8(2) Rental Right Directive. That being said, the precise wording of the article is perplexing: the provision would claim to vest performers and phonogram producers with a 'right', yet states that Member States must 'ensure that a single equitable remuneration is paid by the user', a phrasing that would seem to indicate the imposition of a corresponding and unavoidable obligation on that person. Nevertheless, no decisive result in favour of an unwaivable right can de deducted. We must 
therefore conclude that, in theory at least and on the European level, the performer and phonogram producer are permitted to agree to the relinquishment of any claim to the payment of equitable remuneration. Of course, Article 8(2) Rental Right Directive offers only minimum rights in respect of broadcasting and communication to the public and Member States are free to recognize broader protection for performers and phonogram producers, including through the exclusion of the possibility of waiver.

Below we shall examine in detail the licensing schemes for the collection and distribution of equitable remuneration currently in place in the Netherlands and the UK.

\subsubsection{Collective Management of the Right to Equitable Remuneration in the Netherlands}

The right to equitable remuneration was introduced for the first time in the Netherlands in 1993, with the implementation of the Rental Right Directive. According to Article 7 of the Dutch Neighbouring Rights Act,

A phonogram or reproduction thereof published for commercial purposes may be broadcast or otherwise communicated to the public without the consent of the producer or the performer or their assignees, provided an equitable remuneration is paid. The provisions in the first sentence shall not apply to making such a phonogram available to the public.

Article 15 of the same law provides that,

The equitable remuneration referred to in Article 7 shall be paid to a representative legal person designated by Our Minister of Justice, who shall be exclusively entrusted with the collection and distribution of such remunerations. ${ }^{\text {Ioo }}$

By virtue of this provision, a statutory mandate is established whereby the Stichting ter Exploitatie van Naburige Rechten (Foundation for the Exploitation of Neighbouring Rights - SENA) is, within the Netherlands and to the exclusion of all others, entitled to exercise and maintain the rights granted to performing artists and phonogram producers pursuant to Article $7 \mathrm{WNR} .{ }^{\text {IoI }}$ In other words, in

I00. WNR, Article I5.

Ior. See SENA Exploitation Agreement for Performing Artists, in Koedooder, M.T.M. et al. (eds) (2009), De nieuwe praktijkgids Artiest en Recht: juridische en fiscale informatie, Deventer: Kluwer, p. 531. It should be noted that, by virtue of the exploitation agreement, SENA is also entrusted with collecting equitable remuneration due according to rights and claims that flow from Article I2 Rome Convention and other corresponding provisions of international agreements to which the Netherlands have acceded. 
the Netherlands, for the collection of equitable remuneration, a statutory licensing scheme has been established, with the relevant collecting society's mandate grounded in national law. Rights holders do not need to be registered members of SENA for collection to take place.

The licenses issued by SENA to users can either be granted on an individual basis or through collective licensing agreements concluded with sector-related organizations. They apply on an annual basis and are calculated according to a number of different parameters, such as the number of pupils in a ballet class or the total duration of listening on an internet radio station. As a rule, licensees are offered blanket licenses under the terms of which they can use any of the sound recordings included in SENA's repertoire (repertory-based licenses). It should be noted that SENA also issues licenses for use of phonograms in new media. Thus, such modes of dissemination as the use of mechanical background music on websites, simulcasting or internet radio are included within SENA's field of competence. SENA does not collect remuneration for podcasting (although it is entrusted with processing podcasting licensing on behalf of NVPI, the Dutch association for producers and importers of image and sound carriers). ${ }^{102}$

After collection, SENA redistributes the monies collected to its members on the basis of playlists provided by radio and television stations according to legally approved regulations. SENA's members include both phonogram producers and performers, while membership is necessary for payment by SENA to the performer or phonogram producer to take place. Nevertheless, no assignment of rights is necessary so as to become a member of SENA.

Can a performer and phonogram producer waive their right to equitable remuneration under the Dutch system? In other words, it is (legally and practically) possible for the performer and phonogram producer to license the use of their phonogram for communication to the public or broadcasting to a third party otherwise than through SENA and according to terms different than those existing in the licenses SENA grants to users, e.g. through the use of a Creative Commons license? It can be argued that the Dutch Neighbouring Rights Act does leave this possibility open. Of course, as opposed to Articles 2(6), 5(3) and 6(6) WNR, Article 7 WNR, which introduces the right, does not explicitly provide for the possibility of a waiver. Nevertheless, a closer examination of its precise language does seem to indicate towards waivability; Article 7 states that use of a commercial phonogram in a broadcast or a communication to the public is possible 'without the consent of the producer or the performer or their assignees, provided an equitable remuneration is paid'. This phrasing implies a two-pronged system for legitimate broadcasting or communication to the public, whereby

I02. See 'New Media' on the SENA website. Available at: www.sena.nl/Gebruikersmuziek/ Marketing-lic/Nieuwe-Media.aspx. 
either remuneration is paid or permission is granted by the owners of the related rights. As long as either one of these conditions is met, the act is lawful. ${ }^{103}$ If this interpretation were to be accepted, then the Netherlands would emerge as a country having instituted a waivable statutory licensing scheme.

However, the above analysis is not the generally accepted interpretation in the Netherlands. Instead, SENA's operational practice disregards the possibility of waiver, thereby instituting a de facto non-waivable statutory licensing system. SENA collects equitable remuneration for the use of phonograms for communication to the public or broadcasting in the Netherlands without examining whether they are included in its repertory, that is to say, without considering whether the rights holder or an assignee have provided consent, whether generally or for a specific use in broadcasting or communication to the public. In fact, SENA automatically assumes that even unregistered artists will approve of the collection of monies: whenever SENA finds itself with additional reserves of undistributed revenue, it attempts to get into contact with unregistered artists to explain that remuneration will be distributed to them upon registration. Such remuneration is kept in SENA's 'black box' of unclaimed royalties on the rights holder's behalf for five years. In addition, as a result of cross-licensing agreements with its foreign counterparts, SENA will also collect equitable remuneration for all sound recordings in overseas repertories. If the unregistered artist is a foreign one, the International Performers' Database is checked and inquiries made to the sister organization of the performer's nationality. SENA consequently controls rights over almost the entirety of the worldwide repertoire.

It is important to note that this arrangement means that, even if the above twopronged analysis were to be accepted, such an occasional derogation from the collection of remuneration would be impossible to implement. Given that SENA has an exclusive mandate to collect equitable remuneration in the Netherlands and controls a vast international repertoire, such rare exceptions to the rule, whereby one or more users have been granted permission to use one or more phonograms from the opus of a specific right-holder, would prove impossible to implement into the tariff charged to users (see also below, section 3.3 on the situation in the UK).

The theory posited below may be an alternative route out of this impasse. It may also allow for SENA-independent licensing of the use of phonograms in communications to the public or broadcasts in the Netherlands that result in the release of the user from the obligation to pay equitable remuneration. According to Article 7(4) WNR, in the event of 'disagreement as to the amount of the equi-

I03. Visser, D.J.D. (1999), Naburige Rechten: van Uitvoerende Kunstenaars, Fonogrammenproducenten, Filmproducenten en Omroeporganisaties, Deventer: W.E.J. Tjeenk Willink, p. 77; Visser, D.J.G. (I998), 'Waarheen, waarvoor met Mieke Zelkamp en de SENA?' Informatierecht/ AMI I998, p. 8o. 
table remuneration, the District Court of The Hague shall have sole competence at first instance to determine, on application of either of the parties, the amount of the remuneration'. The ECJ has ruled ('SENA' ${ }^{\text {I04) }}$ that Article 8(2) of the Rental Right Directive does not preclude a model for the calculation of an equitable remuneration that takes variable and fixed factors into account, as long as a proper balance between the interests of both the performing artists and producers and the interests of third parties in being able to broadcast the phonogram on terms that are reasonable is achieved. The height of the equitable remuneration is calculated on the basis of a number of factors, including 'the number of hours of phonograms broadcast, the viewing and listening densities achieved by the radio and television broadcasters represented by the broadcasting organization, the tariffs fixed by agreement in the area of performance rights and broadcasting rights in respect of musical works protected by copyright, the tariffs applied by public broadcasters in Member States bordering on the Netherlands and, finally, the amounts paid by commercial stations'. It is, therefore, conceivable that, if SENA were to agree to such terms or, in the absence of such a contractual agreement, if the District Court of The Hague decided to impose a calculation model that takes account of, in addition to the above, the number of hours communicated to the public or broadcast of, e.g. Creative Commons licensed phonograms, an exploitation method that combined the collection of equitable remuneration and the use of Creative Commons licenses could be implemented in the Netherlands. Thus, if a certain percentage of the total number of tracks broadcast by wireless means or communicated to the public by a certain user are phonograms for which the rights owner has signalled, through the use of a CC license or other means, that he requires no equitable remuneration, the height of the royalties charged for the blanket license would be accordingly lowered. If the music broadcast by wireless means or communicated to the public exclusively consisted of such phonograms, then the equitable height of the total remuneration due would drop to zero.

\subsubsection{Collective Management of the Right to Equitable Remuneration in the UK}

An alternative system is in operation in the UK. As with the Netherlands, remuneration rights in the UK were also only formally introduced in the process of implementing the Rental Right Directive: according to s.I82D CDPA, which implemented Article 8(2) of the Rental Right Directive into UK law, performers are now 'entitled to equitable remuneration from the owner of the copyright in the sound recording' where 'a commercially published sound recording of the whole or any substantial part of a qualifying performance (a) is played in public, or (b) is

I04. Case C-245/00 Stichting ter Exploitatie van Naburige Rechten (SENA) v Nederlandse Omroep Stichting (NOS) (ECJ 6 February 2003). 
communicated to the public otherwise than by its being made available to the public'. Previously, performers had no legal entitlement to income from the communication to the public or broadcasting of their performances, although recording companies had developed a practice of ex gratia payments to certain musicians. Under the new regime, performers claim their revenue from the owner of the copyright in a sound recording, i.e. the record company that published the phonogram. ${ }^{105}$ In practice this responsibility is assumed by Phonographic Performance Limited (PPL), the collecting society that administers the performing and broadcasting rights of the owners of copyright in sound recordings. Up until recently, the collection of remuneration from PPL was done by the performer organizations PAMRA (the Performing Artists' Media Right Association) and AURA (the Association of United Recording Artists). The first of these was mainly used by session musicians, while the second by feature artists and producers, as well as session musicians. A further development ensued in 2006, when PAMRA and AURA merged with PPL. Under this new structure, PPL directly distributes equitable remuneration to its performer members.

This history has left its mark on the current system of collective administration of the right to equitable remuneration. It is characteristic of the UK system that no right to equitable remuneration is provided in law to phonogram producers. Instead, Section I of the CDPA recognizes sound recordings as works in which copyright subsists and Section 9 declares the producer to be the author of a sound recording. Thus, producers of sound recordings are vested with, instead of the mere right to equitable remuneration granted by the related rights systems in force in continental European civil law systems, all exclusive rights recognized to the authors of copyright works. These include the exclusive right to the playing of a work in public (Section I9 CDPA) and the exclusive right of communication to the public (Section $20 \mathrm{CDPA}$ ), which encompasses the making available and broadcasting rights.

PPL holds no exclusive mandate in law - to the contrary, all PPL members assign their rights to the society upon registration and appoint PPL as their agent to exercise them, meaning that PPL's mandate to control and license sound recordings extends only to the sound recordings of its members. In other words, what is in place in the UK is a voluntary licensing scheme. On the basis of this individualized authorization, PPL grants licenses to users and subsequently collects license fees for the broadcasting and playing in public of the sound recordings it controls. PPL then redistributes these monies to the owners of the sound recordings (usually the record company) and (on behalf of the owners) to the performing artists. Distribution is organized on the basis of computerized returns

I05. Bently, L. Bently \& B. Sherman (2004), Intellectual Property Law, Oxford: OUP, p. I44; CDPA I988, ss. 20, I82CA, I82D, 295. 
from major licensees. ${ }^{\text {106 }}$ As in the Netherlands, membership of the performer is necessary for him to participate, in exercise of his right to equitable remuneration, in the distribution of the revenue collected, yet contrary to the Dutch system, membership of the record company that controls the rights in the performer's sound recordings is necessary, not merely for that company to partake of the royalties, but moreover for collection of equitable remuneration for the playing in public or broadcasting of its sound recordings to take place at all. This rule is intended to actually govern PPL's operational practice; the society's website in fact unambiguously states that:

PPL only controls and licenses sound recordings in its repertoire. A sound recording will be in PPL's repertoire if:

- The sound recording qualifies for copyright protection, and

- The record company that controls the rights in that sound recording is a member of PPL [...] or is a member of a record company society in another territory, with whom PPL has a repertoire agreement. ${ }^{\text {107 }}$

Nevertheless, the UK system is not as dissimilar to the Dutch non-waivable licensing system as might initially appear: although not exclusively entrusted with the collection and distribution of equitable remuneration, PPL is currently the only collecting society of its kind within the UK and has grown to represent over 3,000 record companies and 38,000 performers. In addition, as a result of crosslicensing agreements with its foreign counterparts, PPL also collects equitable remuneration for sound recordings in overseas repertories. Like SENA, therefore, it administers rights over more or less the entirety of the worldwide repertoire.

The licenses issued by PPL to users can either be granted on an individual basis or through collective licensing agreements concluded with sector-related organizations. Licenses are available on an annual basis or for a one-off event, with tariffs varying according to average attendance and hours per occasion. PPL also varies its standard license fees according to the type of broadcasting or communicating to the public effected, branching from traditional commercial radio to use of a sound recording as an accompaniment to a fashion show or a pop quiz. In general, licensees are offered blanket (repertory-based) licenses under the terms of which they can use any of the sound recordings included in PPL's repertoire. ${ }^{\text {I08 }}$

Io6. Torremans P. (2006), 'Collective Management in the United Kingdom (and Ireland)' in D. Gervais, Collective Management of Copyright and Related Rights, Alphen aan den Rijn: Kluwer Law International, p. 237.

I07. PPL website. Available at: www.ppluk.com/en/Performers/UK-revenue-payments/.

I08. Torremans, P. (2006), 'Collective Management in the United Kingdom (and Ireland)' in D. Gervais, Collective Management of Copyright and Related Rights, Alphen aan den Rijn: Kluwer Law International, p. 237. 
Licenses are offered by PPL for new as well as traditional media. These include such services as non-interactive internet radio or customized radio. ${ }^{109}$ PPL does not currently collect remuneration for podcasting. In any case, an important dissimilarity in approach on the part of PPL towards new media, as opposed to traditional media, should be noted: in the case of new media the assignment of rights to PPL undertaken by a member upon joining the society is non-exclusive. This is not the case for traditional media. This means that a PPL member may license the right to play in public and broadcast exclusively via new media (e.g. via internet radio) to a third party directly and not through PPL. This flexibility is not available in the case of simulcasting (the assignment of rights to PPL for simulcasting a sound recording is exclusive).

Is the right to equitable remuneration waivable on the part of the right-holder under the UK system? According to s. $182 \mathrm{D}(7)$ of the CDPA, '[a]n agreement is of no effect in so far as it purports to exclude or restrict the right to equitable remuneration under this section'. ${ }^{\text {IIo }}$ Yet, given that s. I82D CDPA regulates the payment of equitable remuneration by phonogram producers to performers, we must conclude that only an agreement between two such parties is foreclosed (i.e. PPL cannot exclude performing artists that are PPL members from an equitable share of licensing fees gathered). The possibility of waiver of the right to equitable remuneration on the part of the performer and phonogram producer to the benefit of the user is not affected, although this will only be possible for owners of related rights who are not PPL members and who have not therefore given an exclusive mandate to the society. As mentioned above, it is not PPL's policy to collect remuneration for sound recordings of non-members, in line with the UK's voluntary licensing system. Thus, rights holders who have not joined PPL retain control over the decision of whether or not they will demand royalties of the user for the transmission of their sound recordings.

Finally, it should be noted that, according to section $182 \mathrm{D}(4) \mathrm{CDPA}$, in the event of disagreement as to the amount payable by way of equitable remuneration, the person by or to whom it is payable may apply to the Copyright Tribunal to determine the height of the fee. ${ }^{\mathrm{III}}$ Again, this provision, given that the equitable remuneration is, according to UK law, paid by the copyright-owner to the

Io9. Customized radio is defined by PPL as 'online radio services that allow the user to skip sound recordings streamed in the service, pause the stream, and rate sound recordings in order to influence the content that they receive. Users are not allowed to influence the playlist to the extent that they control which track they will be streamed at any given time and the license does not allow the user to fast forward, rewind, repeat or skip back. All services must be streamed and non-downloadable'. See PPL website. Available at: www.ppluk.com/en/Music-Users/Onlineand-mobile-radio/Customised-Radio/.

IIo. The Copyright, Designs and Patents Act (ST I988 c. 48) (hereafter: CDPA I988) permits performers to assign their right to equitable remuneration in accordance with s.I82 $\mathrm{D}(2)$.

III. CDPA, s. I82D(4). 
performer, does not influence the height to the fee paid by the user. Instead, s. II8 and II9 CDPA entrust the Copyright Tribunal with reviewing the terms of licensing schemes of licensing bodies and one-off licenses respectively, after reference on the part of either individuals claiming to require licenses or a representative organization of such individuals. The Tribunal is granted the power to confirm or vary licensing schemes, either generally or so far as cases of the description to which the reference relates are concerned, as well as individual licenses, according to the criterion of 'reasonableness'. ${ }^{\text {II2 }}$ Similar to the Dutch situation, therefore, a decision of a judicial authority could, in the UK as well, initiate a re-examination of the current licensing scheme, in this case in order to take account of the percentage of tracks played in public or broadcast by a certain user that are not PPL-managed, and for which, therefore, the collection of royalties by PPL is arguably unreasonable (compare section 3.2.). PPL itself could, of course, also spontaneously, or after negotiations with users, decide to adjust its license fees to take account of such situations. Due to the fact that PPL takes an exclusive assignment of rights by members upon their registration, an arrangement such as that described above would not result in a situation where it is possible to actually combine collective management of related rights with independent licensing methods, e.g. through Creative Commons, as would be possible in the Dutch hypothesis. In the UK, the adjustment of the royalties owed would simply take account of the number of tracks played or broadcast whose producers are not PPL members and who, therefore, have retained the right to opt for alternative licensing methods, including via Creative Commons. Thus, such a scheme would more accurately reflect PPL's stated policy of collecting royalties only for sound recordings included in its repertoire.

\subsubsection{The Functional Reality of Collecting Societies}

The section above analyzed the legal provisions governing the operation of collecting societies entrusted with the collection of equitable remuneration for the communication to the public and broadcasting of phonograms in the Netherlands and the UK. In both the Dutch and the UK situations, however, theoretical possibility is worlds apart from practical application. As mentioned previously, whether we consider Dutch law to establish a waivable or a non-waivable statutory licensing system, the fact remains that SENA's operational practice does not account for the possibility of waiver and the foundation will collect fees from users regardless. PPL does make a distinction between the sound recordings of members and non-members, yet its vast repertoire and practice of offering blanket licenses negate any practical effect this policy might have. In both countries,

II2. CDPA, ss. II8-I20. See also Bently, L. \& B. Sherman (2004), Intellectual Property Law, Oxford: OUP, pp. 286-287. 
the existence of cross-licensing agreements with foreign sister organization exacerbates this situation further, by extending the collecting societies control to essentially all phonograms in existence. If a user wants to broadcast or communicate sound recordings to the public, but wishes to avoid paying monies to PPL, she will be severely limited in her choice of music. Occasionally including a couple of sound recordings the use of which has been individually negotiated with the rights holder to her usual playlist will not affect the height of the tariff for the blanket license that must anyway be paid to SENA or PPL. The only way to achieve such an effect would necessitate either a court decision by the District Court of The Hague and the Copyright Tribunal respectively or a unilateral decision of the collecting society, possibly after negotiations with users. It should be noted that the organizations' strong bargaining positions are unlikely to motivate them in this direction. Alternatively, users may circumvent the obligation to pay equitable remuneration through, depending on the license system in place, either the exclusive use of sound recordings of unaffiliated creators or the careful avoidance of uses that trigger the application of the right to equitable remuneration. In the past, this would have been exceedingly cumbersome to organize, but nowadays, with the advent of modern digital technologies and the introduction of open content licenses, it has become not only a feasible, but also an attractive alternative.

\subsection{Attaching Creative Commons Licenses to Sound Recordings}

\subsubsection{The Creative Commons Licensing Suite}

As already explained briefly in the Introduction, Creative Commons is a non-profit organization which has developed a set of open content licenses. These are intended to provide creators with a simple tool to help them indicate which particular rights they wish their works to carry and which they wish to relinquish. The objective is to enable the free use of works, within the customized limits set by the licensor, on the part of users. These customized limits may include any of the following options:

- Attribution (BY): Licensees may copy, distribute and publicly perform the copyrighted work (even commercially and including through derivative works based upon it), but only if they credit the author in the manner requested in the license. Since the implementation of version 2.0 of the CC licenses, the Attribution clause is a mandatory feature of all CC licenses.

- Non-Commercial (NC): Licensees may copy, distribute and publicly perform the copyrighted work - and derivative works based upon it - but for non-commercial purposes only.

- No Derivative Works (ND): Licensees may copy, distribute and publicly perform only exact copies of the copyrighted work, not derivative works based upon it. 
- Share Alike (SA): If a licensee does create a derivative work, he may distribute or publicly perform the work only under the terms of the same CC license as the one applied to the original work or another compatible license. ${ }^{\mathrm{II}}$

Mixing and matching these requirements leads to the six basic Creative Commons licenses: Attribution (BY), Attribution Share Alike (BY-SA), Attribution No Derivatives (BY-ND), Attribution Non-Commercial (BY-NC), Attribution NonCommercial Share Alike (BY-NC-SA) and Attribution Non-Commercial No Derivatives (BY-NC-ND).

Can a performer and phonogram producer attach a Creative Commons license to their sound recording? If they were only vested with exclusive rights, no problem would occur. Difficulties arise, however, in view of the right to equitable remuneration, due to the licensing systems establish by national legislators to ensure more effective management. In order to secure the validity of the Creative Commons licensing suite within such licensing systems, each Creative Commons license includes a provision in its Legal Code ${ }^{\mathrm{II} 4}$ clarifying the rules governing the compatibility of the license with non-waivable compulsory statutory license schemes, waivable compulsory statutory license schemes and voluntary license schemes. Given the framework set up by these license terms, under which circumstances will attaching a Creative Commons license absolve the user from the obligation to pay remuneration fees to the rights holder and when will the licensor and licensee be bound by the provisions of the legal system within which they operate? Is there any behaviour the user can adopt so as to avoid the payment of equitable remuneration to a collecting society?

\subsubsection{Creative Commons and Non-Waivable Compulsory License Schemes \\ According to the Legal Codes of the six Creative Commons licenses,}

In those jurisdictions in which the right to collect royalties through any statutory or compulsory licensing scheme cannot be waived, the Licensor reserves the exclusive right to collect such royalties for any exercise by You of the rights granted under this License.

In other words, when a non-waivable statutory licensing scheme is in place (as is generally accepted to be the case in the Netherlands, see section 3.2 above), the application of the license will be thoroughly valid, but the user will be obliged to

\footnotetext{
II3. Creative Commons, 'License Your Work'. Available at: http://creativecommons.org/ about/license/.

II4. For a brief explanation of what the Legal Code constitutes, see above $\mathrm{ft}$. I.
} 
pay an equitable remuneration fee. This arrangement is sensible; otherwise, under the provisions of national law, the consumer would still be obliged to pay despite the attachment of the license, the only difference being that, if not claimed by the owner herself, the remuneration would simply accrue to the collecting society or to other members of the society who have not chosen to license their phonograms under Creative Commons. ${ }^{\mathrm{II}}$ So, for example, in the Netherlands, under the current regime, even if a user exclusively makes use of a communication to the public or broadcasting by wireless means of phonograms released to the public by the performers and phonogram producers that created them under the terms of a Creative Commons license, that user will still be under an obligation to pay remuneration to SENA, whether or not the performers and phonogram producers are SENA members.

Is there a way for the user to circumvent the payment of equitable remuneration to the collecting society? The only possibility would be through avoidance of uses that fall within the field of application of the right to equitable remuneration. The field of application of the right to equitable remuneration was discussed extensively in section 2 of this chapter. Applying that analysis to the specific situation of a phonogram released under a Creative Commons license within the context of the Dutch non-waivable statutory licensing system, it can be deduced that no obligation to pay equitable remuneration will arise if either of the following apply:

I. The phonogram to which the Creative Commons license has been attached is not a phonogram published for commercial purposes. In the Netherlands, however, a phonogram will be considered to be published for commercial purposes when it has been made available in such a way that members of the public may access it from a place and at a time individually chosen by them (Article 7(2) WNR). Given that the vast majority of phonograms released under the terms of a Creative Commons license will be released online (as opposed to through the publication of physical copies), avoiding the use of commercially published phonograms will presumably be difficult for CC licensees to achieve.

2. Alternatively, the user of a phonogram that has been released under the terms of a Creative Commons license, but is considered to be commercially published, can opt for exclusively using the phonogram in services that do not fall within the categories of communication to the public or broadcasting. In other words, the user will have to make sure his website only ever makes such phonograms available to the public in such a way that members of the public

II5. Van Eechoud, M. \& B. van der Wal (2008), 'Creative commons licensing for public sector information - Opportunities and pitfalls'. Available at: www.ivir.nl/publications/eechoud/ CC_PublicSectorInformation_report_v3.pdf. 
may access them from a place and at a time of their own choosing, through the means of, e.g. on-demand radio. The user can also opt for uses such as podcasting, for which, whether they fall within the field of application of the right to equitable remuneration or whether it is unclear if they do so or not, SENA (currently) collects no remuneration,.

If national legislation provides rights holders with stricter protection, the user will have to avoid violating the terms set in the corresponding domestic provisions.

\subsubsection{Creative Commons, Waivable Compulsory License Schemes and Voluntary License Schemes}

According to the Legal Codes of the six Creative Commons licenses: ${ }^{\mathrm{II} 6}$

In those jurisdictions in which the right to collect royalties through any statutory or compulsory licensing scheme can be waived, the Licensor waives the exclusive right to collect such royalties for any exercise by You of the rights granted under this License.

and

The Licensor waives the right to collect royalties, whether individually or, in the event that the Licensor is a member of a collecting society that administers voluntary licensing schemes, via that society, from any exercise by You of the rights granted under this License.

In other words, when a voluntary statutory licensing scheme (as is the case in the UK) or a non-waivable statutory licensing scheme (as would be the case in the Netherlands, if the alternative interpretation of Article 7 WNR suggested in this chapter were accepted, see section 3.2 above) is in place, the Creative Commons licenses require that the licensor waive the right to collect royalties for any exercise of rights on the part of the licensee, including the right to equitable remuneration for the broadcasting or communication of the phonogram to the public.

In this context, whether or not the rights owner is already a member of a collecting society proves significant: if so, depending of course on the particular terms of the contract between the rights owner and the society, it is likely that the rights owner's entire repertoire will be collectively managed by the society with no possibility of derogation through the application of a Creative Commons license. The licensor will probably have assigned the right to equitable remuneration for

II6. See $\mathrm{ft} .3$ above on the diverging language of the terms in the $\mathrm{CC}$ licenses related to license schemes depending on the type of license. 
use of his phonogram for broadcasting or communication to the public to the collecting society and granted it an exclusive mandate to license such use, thereby stripping herself of the right to license the rights for such uses via a Creative Commons license. This is indeed the case with the terms of contracts signed by members of the UK's PPL: the phonogram producers (authors of the sound recording according to UK law) assign their exclusive rights over to PPL upon registration, including the rights of communication to the public and the right to play the phonogram in public. PPL, then, is under a non-waivable obligation flowing from s.I82D(4) CDPA to pay the performer equitable remuneration. Accordingly, attaching a CC license to a sound recording managed by PPL is not possible under UK legislation.

As noted above, the mandate provided by PPL members to the PPL specifically for new media is a non-exclusive one. This means that a performer and phonogram producer can provide consent for use of their sound recording for communication to the public via new media to a user without that user being obliged to pay royalties to PPL. Nevertheless, such consent may not be provided via the mechanism of Creative Commons licenses. This is in fact due to the terms of the CC-licenses themselves: no distinction is made within the licenses between traditional and new media. The rights holder who attaches a Creative Commons license to her sound recording cannot specify that permissions given to the user apply only in the case of new media.

If the rights owner is not a member of a competent collecting society established within a voluntary license scheme (e.g. is an independent producer in the UK) or a waivable compulsory license scheme or if he is a member of such a society, but has not assigned his rights to the collecting society (e.g. within the hypothetical construct of a Dutch waivable compulsory license scheme, is either an independent producer or a member of SENA, for which no assignment of rights is necessary), the attachment of a Creative Commons license to the phonogram will be thoroughly valid. Moreover, such attachment will bring the waiver clauses presented above into play, thus releasing the user from the obligation to pay equitable remuneration - the licensor would already, through the release of the sound recording under the terms of the Creative Commons license, have waived the right to collect equitable remuneration.

Nevertheless, in practice, such a strategy is likely to prove unworkable. As analyzed above, in their dealings with users, collecting societies will usually issue blanket licenses that authorize unrestricted access to the repertoire they administer. ${ }^{\text {II7 }}$ This arrangement makes singling out a particular track from a member's repertoire impossible, meaning that the attachment of a Creative Commons li-

II7. Katz, A. (2005), 'The Potential Demise of Another Natural Monopoly: Rethinking the Collective Administration of Performing Rights', J. Competition L. \& Econ. I: 54I. 
cense by that member to that particular track will not be reflected in the tariff charged to users. If the rights holder is not a member of a collecting society, the following scenario will come into play: the collecting society is likely to operate in a de facto monopolistic manner within national borders, administering, through cross-licensing agreements with other foreign societies, rights over more or less the entirety of the global repertoire. As a result, the release of a specific track under the terms of a Creative Commons license will have no noticeable effect on the expenditures of a given user: she will still be obliged to invest in a blanket license with the responsible collecting society, so as to legally broadcast or communicate to the public tracks that are not CC-licensed and in that society's repertoire, i.e. the vast majority of tracks in existence, while the lack of a single track or artist will not influence the height of the tariff charged. The only tangible result of the licensing will be the exclusion of the right-owner from the distribution of monies collected. If the rights holder is a member of the competent collecting society, the exact same problem arises, the only difference being that the rights holder is no longer excluding herself from participating in the redistribution of equitable remuneration collected on the part the society to its members.

A single viable escape route from this system would be through the careful assimilation on the part of the user of playlists containing material exclusively licensed under Creative Commons, thereby cutting off all ties with collective management societies. The user could also add an additional layer of protection by choosing to avoid uses that constitute communication to the public or broadcasting or limiting all communication to the public and broadcasting to phonograms that have not been commercially published, as would be the case in a non-waivable compulsory license scheme (see section 4.2 above).

Finally, it is worth pointing out that the above conclusions hold true for all six licenses in the Creative Commons licensing suite, irrespective of the specific conditions chosen by the right-holder. As explained above, the licenses introduce diverging terms depending on which freedoms the licensor wishes to grant to the user and what limitations he wishes to place on these freedoms. This is because the relevant international, national and European provisions do not make any distinction between whether a use is made for commercial purposes or not, whether the user creates a derivative work based on the licensed one or whether the user attaches a similar Creative Commons license to such a work. Equitable remuneration is due regardless.

\subsubsection{In Practical Terms: Last.fm and Simuze.nl}

To better elucidate the consequences of the application of a Creative Commons license by the rights holder in the various license systems analyzed above and the behaviour the user can adopt to limit the obligation of paying equitable remuneration for the communication to the public or broadcast of phonograms to 
which a Creative Commons license has been applied, the following two examples of online music services are useful: ${ }^{\text {Ir8 }}$

(a) Last.fm is a UK-based internet radio and music community website on which users can listen to music in two distinct manners: either they can tune in to a radio station of their selection or listen to previews. On the basis of the first method, the user can select among a variety of different channels: one based on her own or another user's personal Library containing previously played tracks or added artists; one consisting of Recommendations generated automatically by Last.fm; channels playing music of a specific genre or of similar artists; etc. Subscribers can further listen to radio stations tuned in to play pieces to which they've assigned the terms of 'Loved Tracks', added to their own personal Playlists or tagged with a Personal Tag. In other words, even subscribing users cannot actually choose which piece they will hear and the time at which they will hear it. What all users are offered is the faculty of selecting the general genre they wish to hear through a variety of mechanisms, while every track they play and their reaction to it ('loved'/'banned') updates their Last.fm profile as to their preferences. ${ }^{\text {II }}$ Thus, it appears that Last.fm offers what PPL has labelled 'customized radio'; the music played on Last.fm is selected through software attuned to each user's particular tastes, instead of those of the traditional radio DJs. Yet the DJ is not actually substituted by the user, since absolute control is not on offer.

The second way of listening to music on Last.fm is through the Previews. These can be selected by the user at a time and place of her choosing, but the full track will usually not be played - a 30-second sample will be offered instead. An exception is provided to users in the UK, US and Germany: Last.fm offers a service called Free On-Demand to users located in these countries,

II8. The observations made in this chapter are based on options offered on the websites of Last.fm and Simuze.nl as they were in December 2009.

II9. It should be noted that the free channels on Last.fm are only fully available to users who live in the UK, US or Germany. Users from other countries are only allowed a 30-track trial, after which subscription to the site is required. This conclusion is derived from the current terms in force for the Buma/Stemra pilot project for musical works. According to Appendix 4 of the 'Special Conditions for the Buma/Stemra Agreement with Regard to Non-Commercial Creative Commons Licences', the term 'commercial use' encompasses any 'for-profit' activity, including the making available online and communication to the public of the work in exchange for payment or other forms of financial compensation, such as the use of the work in combination with advertisements, advertising campaigns or any other kind of activity whose purpose is to generate income for the user or a third party. For a digital copy of the Agreement in Dutch, see: www. bumastemra.nl/nl-NL/MuziekrechtenVastleggen/Pilot+Creative+Commons/Speciale+voorwaarden.htm. 
allowing them to listen to specific pieces up to three times in full length. Afterwards, these tracks too will revert to the 30-second preview norm.

(b) Simuze.nl is a Dutch online open content community. Simuze users can upload music onto the site under the terms of a Creative Commons license. In order to do so, users must be the sole rights holders, i.e. composers of the music, authors of any lyrics, performers and producers of the final track. In the case of collaborative works with multiple authors, consent will have to be obtained by all before the work can legally be made available on Simuze. $\mathrm{Mu}$ sic that has entered the public domain may also be uploaded. Once on the site, the music can be downloaded or streamed by users on an on-demand basis. Recently, Simuze has also added an internet radio service which exclusively plays tracks released under Creative Commons terms on its website. A final possibility involves listening to playlists of tracks compiled by Simuze users.

What happens when sound recordings are played on each of these two websites? At the time when Simuze only provided online music services on an on-demand basis, whether downloading/streaming individual tracks or playlists, no equitable remuneration had to be paid to SENA. Instead, the rights holders' exclusive rights under Article 3(2) of the InfoSoc Directive had to be cleared for the making available of their work to the public. On Simuze, this is achieved through licensing under the terms of the Creative Commons licenses.

The various radio channels of Last.fm, on the other hand, present a different story. When streamed on Last.fm, a track is not being made available to the public from a place and at a time individually chosen by each member of the public, but is instead communicated to the public within the sense of Article 8(2) Rental Right Directive. Equitable remuneration is paid by the site to the performers and phonogram producers responsible for its creation. Last.fm's Free On-Demand service brings the making available right back into play and, thereby, the need to clear exclusive rights. Presumably, it is for this precise reason that the service is only available in a limited number of countries and for a limited number of playings: negotiating the clearance of exclusive rights is a more expensive and complicated business than paying remuneration fees to a single collecting society under a prefixed scheme.

However, now that Simuze has started offering its CC-licensed material in the form of an automatically generated radio service, similar to that provided by Last.fm, Article 7 of the Dutch Neighbouring Rights Act becomes relevant: under the current Dutch non-waivable statutory licensing system, SENA has the right to collect monies from Simuze and Simuze has the obligation to pay remunerations despite the attachment of a Creative Commons license to the sound recordings that it plays. One legal line of argumentation that could possibly enable avoidance of this eventuality would be the following: if the alternative interpretation of the 
phrasing of Article 7 WNR were accepted and we were to acknowledge that a waivable compulsory license system was in operation in the Netherlands instead of a non-waivable one, remuneration fees would not have to be paid, in derogation to the norm, as the rights holders' consent would have already been provided by means of the CC license. This would be possible whether or not the rights holders were members of SENA, due to the fact that SENA membership does not require any assignment of rights on the part of the owner of related rights.

If Last.fm attempted to exclusively play CC-licensed sound recordings and if the producers of the tracks played on its radio stations were not PPL members, under UK law, equitable remuneration would likewise not be due: the rights holders would have, through the application of the CC license, waived all remuneration rights. Given that PPL can only collect fees for the works listed in their repertoire, no mandate to collect equitable remuneration exists for the phonograms of non-members. Nevertheless, the advantages of such a scheme for Last.fm are not prominent: as long as the site wishes to continue playing the extensive collection of material managed by PPL, blanket licenses covering this material must still be entered into with PPL, while the height of the royalties accordingly due would remain unaffected. The subtlety of cleared rights for a limited number of tracks loses its significance in comparison to the vast repertoire of PPL and in the face of a blunt system geared towards efficient collection. The only measurable consequence that would ensue would be that the exclusion of the right-owners who licensed their work under Creative Commons and are not members of PPL from a share of the redistributed remunerations.

\subsubsection{Flexible Collective Management and the Right to Equitable Remuneration}

It seems evident from the analysis above that a flexible collective management system would not be necessary to enable the use of Creative Commons licenses in the area of related rights, as it is in copyright. The terms of the CC licenses preclude this. The CC clauses on the different license systems ensure the validity of the attachment of a CC license to a phonogram: the only thing at stake is the release of the user from the payment of the equitable remuneration. Could a project such as the Buma/Stemra pilot, which aims to enable rights holders to both make use of Creative Commons licenses and be members of a collecting society, help address this issue? When collective management is activated, remuneration is collected in all cases of use of a phonogram in broadcasting or communications to the public and rights owners cannot halt the collection of equitable remuneration on their behalf, thus mixing and matching different methods of exploiting their sound recordings; instead they are forced into a take-it-or-leave-it system in which they either join the collecting society and receive remuneration or abstain from equitable remuneration completely, although the user might still be charged. This means that, if performers and phonogram producers are to 
combine these two methods (Creative Commons licensing and collective management) of exploiting their sound recordings, with the objective of releasing users from the obligation to pay equitable remuneration, the only path available to them would be precisely such a cooperative project.

Yet, in the field of related rights, a stumbling block appears: depending on the jurisdiction, the collecting society will not always be afforded the discretion to decide when to collect remuneration and when to abstain from collection, but invariably will be required to collect. That will be the case, for example, in the non-waivable statutory remuneration system currently in force in the Netherlands; SENA collects remuneration regardless of whether or not the rights owners are SENA members and whether or not they have consented to the use of their phonogram in a broadcast or communication to the public without payment of equitable remuneration. In this situation, it would be worth considering a flexible collective management system based on an agreement between SENA and representatives of users such as that envisioned in section 3.2. above, whereby the percentage of CC-licensed material broadcast or communicated to the public by a user influences the amount of the fee payable to the point where a 100\% CClicensed repertoire corresponds to an equitable remuneration of zero. Such a system can also be imposed onto SENA by the District Court of The Hague, according to the provisions of Article 7(4) WNR. Conceivably the scheme could be limited to only certain types of CC-licenses, such as those with a non-commercial clause.

Almost the same situation would evolve should the alternative interpretation of Article 7 WNR suggested above (see section 3.2.) be accepted and a waivable compulsory license system instituted in the Netherlands. In such a case, the rights owner would have the right to consent to certain uses of his phonogram for broadcasting or communication to the public. For all uses for broadcasting or communication to the public to which the rights owner had not consented, the user would be obliged to invest in a blanket license from SENA, whose level will not have been adjusted, however, to take account of the number of CC-tracks of which the user makes use. The advantage of a flexible collective management system in this situation would lie in the circumvention not of legal imperatives or the contractual terms of the CC licenses, but of SENA's current operational practice.

In the UK, the system is a voluntary licensing one and membership of the phonogram producer in PPL comes with the assignment of rights, meaning that the right to release a phonogram under a CC license is realized solely in the ability of the rights owner to abstain from PPL membership and thereby not partake of the monies distributed. In addition, s. I82D CDPA precludes any agreement between PPL and performers that would exclude or restrict the right of the performer to equitable remuneration - a flexible collective management project that enabled performers to reject equitable remuneration for some uses of their phonogram in 
a communication to the public or a broadcast (e.g. commercial uses) would be contrary to UK legislation. What could be implemented, either through an order of the Copyright Tribunal or a decision of PPL itself, would be a system in which the level of the fee payable would be lowered according to the number of nonPPL-managed (and therefore possibly even CC-licensed) tracks in the user's playlists.

Would the scheme have an impact on the options open to websites such as Simuze or Last.fm? Last.fm would probably be indifferent to the project, given that the huge number of PPL-managed tracks they play makes a license an imperative and the effect that non-PPL tracks could have on the level of the royalties payable minimal. Simuze, on the other hand, would benefit from a flexible collective management scheme that allowed for internet radio stations playing music licensed under a Creative Commons license, with adjusted or zero equitable remuneration payable to SENA. If the scheme was one that only permitted the use of Non-Commercial Creative Commons licenses however, it is likely that (depending of course on the specific terms of the scheme) neither site would qualify for participation, as both feature advertisements on their webpages. Last.fm in addition charges users for subscriptions. ${ }^{\text {I20 }}$

What certainly does emerge as a concrete solution from the analysis above is the fact that the existence of a statutory licensing system, whether compulsory and waivable, compulsory and non-waivable or voluntary, for the collection of the equitable remuneration payable to performers and phonogram producers for the use of their phonograms for a communication to the public and broadcasting by wireless means, does not interfere with the operation of flexible collective management schemes in the field of copyright. As long as the owner of the rights in the sound recording has not assigned his rights to a collecting society and has, therefore, retained the right to grant Creative Commons licenses over his phonograms, the additional application of a CC license to the corresponding sound recording will be entirely valid and, moreover, it will be independent of the terms of the license (Commercial/Non-Commercial, Share Alike or not, Derivatives or No Derivatives). The only caveat is that, depending on the nature of the licensing system in place (non-waivable compulsory license scheme/ waivable compulsory license scheme/ voluntary license scheme), and whether the phonogram is com-

I20. This conclusion is derived from the current terms in force for the Buma/Stemra pilot project for musical works. According to Appendix 4 of the 'Special Conditions for the Bumal Stemra Agreement with Regard to Non-Commercial Creative Commons Licences', the term 'commercial use' encompasses any 'for-profit' activity, including the making available online and communication to the public of the work in exchange for payment or other forms of financial compensation, such as the use of the work in combination with advertisements, advertising campaigns or any other kind of activity whose purpose is to generate income for the user or a third party. For a digital copy of the Agreement in Dutch, see: www.bumastemra.nl/nl-NL/MuziekrechtenVastleggen/Pilot+Creative+Commons/Speciale+voorwaarden.htm. 
mercial in nature or not, as well as the preferred mode of delivery of the user and the operational practice of the collecting society, equitable remuneration may or may not still have to be paid by her to the competent collecting society, in accordance with the conclusions drawn in sections 4.2 and 4.3 of this chapter.

\subsection{Conclusion}

When contemplating the application of Creative Commons licenses to musical works in the context of the user's obligation to pay equitable remuneration to the performer and phonogram producer for use of a phonogram in a communication to the public or broadcast, these are the main circumstances to keep in mind:

(a) Whether the work has been published for commercial purposes;

(b) Whether the work is offered by the user on an interactive, on-demand basis;

(c) What type of licensing scheme is established in the country in question for the management of the right.

If the work has not been published for commercial purposes, no remuneration fee need be paid by the user. In most countries, making the work available by wire or wireless means through an on-demand service will qualify as publication for commercial purposes, regardless of the presence or lack of actual commercial intentions. Therefore, we conclude that a rights holder who has placed her sound recording on the internet under the terms of a Creative Commons license in such as way that members of the public may access the work at a time and place of their own choosing, has indeed published that sound recording for commercial purposes, within the meaning of Article 8(2) Rental Right Directive on the right to equitable remuneration. Whether the same will be true for a rights holder who has published his phonogram through the traditional means of physical copies in a reasonable quantity and under the terms of a Creative Commons license remains unclear.

If the work is subsequently offered by the user through an on-demand service, however, Article 8(2) Rental Right Directive will not apply, seeing as the making available of works on an interactive basis does not constitute part of the communication right in the area of related rights. If, on the other hand, the work is broadcast or communicated to the public by the user, either through traditional media or through such new services as webcasting, simulcasting, internet radio or near-on-demand services, Article 8(2) foresees an equitable remuneration right for the performer and the phonogram producer and a question will arise as to whether the application of the CC license can preclude the collection of such remuneration. 
The type of the licensing scheme established for the management of the right will not prevent the validity of the attachment of a Creative Commons license, unless of course the related rights owner has assigned her rights to the competent collecting society. The terms of the CC licenses themselves ensure this result, by foreseeing different consequences for the attachment of the license depending on the system within which it takes place. What the type of the licensing system does affect is whether or not the user will subsequently be obliged to pay equitable remuneration: in the case of non-waivable compulsory license schemes, equitable remuneration must still be paid, however in the case of waivable compulsory license schemes or voluntary license schemes, the licensor waives the right to collect royalties. Yet in practice, the ability to give any substantial meaning to these terms will not solely be influenced by the legal provisions in effect or the contractual terms of the CC licenses, but in addition by the operational practice of the competent collecting society: in systems where collecting societies control extensive repertoires, the relatively small number of CC-licensed phonograms dwindles in significance and cannot influence the height of the fee that must be paid by the user for a blanket license.

Alternatively, the collecting society or the courts can support the release of the user from the obligation to pay equitable remuneration for the broadcast or communication to the public of CC-licensed material: the collecting society might decide, either on its own initiative or by judicial order, to adopt a model for the calculation of the height of equitable remuneration that takes account of the percentage of CC-licensed phonograms in the user's repertory. Where permitted by the legal framework, such a system could even conceivably take the form of a flexible collective management system that enables rights holders to both take advantage of the collective management of some phonograms and release others under the terms of a CC license. Although a flexible collective management system is not necessary in the area of related rights so as to enable the valid attachment of a CC license, it might be useful in enabling rights holders to take full advantage of the opportunity presented by Creative Commons to achieve a broad dissemination of their work on a royalty-free basis by ensuring that the attachment of a license to their phonogram has actual and not just theoretical effect. The terms of the Creative Commons license under which the phonogram is published or which are agreed upon as part of a flexible collective management system do not influence these results. 